\title{
microRNAs and Corresponding Targets Involved in Metastasis of Colorectal Cancer in Preclinical In Vivo Models
}

\author{
ULRICH H. WEIDLE, ULRICH BRINKMANN and SIMON AUSLAENDER \\ Large Molecule Research, Roche Pharma Research and Early Development (pRED), \\ Roche Innovation Center Munich, Penzberg, Germany
}

\begin{abstract}
The high death toll of colorectal cancer patients is due to metastatic disease which is difficult to treat. The liver is the preferred site of metastasis, followed by the lungs and peritoneum. In order to identify new targets and new modalities of intervention we surveyed the literature for microRNAs (miRs) which modulate metastasis of colorectal cancer in preclinical in vivo models. We identified 12 upregulated and 19 down-regulated miRs corresponding to the latter criterium. The vast majority $(n=16)$ of identified miRs are involved in modulation of epithelial-mesenchymal transition (EMT). Other categories of metastasis-related miRs exhibit tumor- and metastasis-suppressing functions, modulation of signaling pathways, transmembrane receptors and a class of miRs, which interfere with targets which do not fit into these categories. Finally, we discuss the principles of $m i R$ inhibition and reconstitution of function, prospective clinical evaluation of with miR-related agents in the context of clinical evaluation in metastasis relevant settings.
\end{abstract}

Colorectal cancer (CRC) is the third most frequently diagnosed cancer worldwide with an annual incidence of 1.4 million new cases and 700,000 deaths worldwide (1). Although about half of the subjects with CRC can be cured by surgery and multimodal treatment, therapy options are limited for patients with metastatic disease (2), despite many

This article is freely accessible online.

Correspondence to: Ulrich H. Weidle and Simon Ausländer, Roche Innovation Center Munich, Roche Diagnostics GmbH, Im Nonnenwald 2, D-82372 Penzberg, Germany. Tel: +49 88566013901 , email: weidle49@t-online.de (UHW), simon.auslaender@roche.com (SA)

Key Words: Epithelial-mesenchymal transition (EMT), invasion and migration, in vivo metastasis-related models, microRNA (miR), miRrelated therapeutic agents, liver metastasis, oncogenic signaling pathways, TGF $\beta$ signaling, tumor- and -metastasis suppressors, review. of the molecular alterations associated with progression from polyps, carcinoma and metastatic disease have been resolved $(3,4)$. Less than $5 \%$ of CRCs are inherited syndromes, such as the Lynch syndrome, formerly known as hereditary nonpolyposis colorectal cancer (HNPCC) and familial adenomatous polyposis (FAP) (5). Lynch syndrome is caused by inherited mutations in mismatch repair genes and FAP is due to inactivating mutations in adenomatous polyposis coli (APC), a negative regulator of wingless and Int-1 (WNT) signaling (5). CRC is a heterogeneous disease at the intertumoral and intratumoral level with molecularly defined subgroups that differ in their prognosis and response to treatment (6). Subtypes characterised by chromosomal instability (CIN), microsatellite instability (MSI) or $\mathrm{CpG}$ island methylator phenotype (CIMP) have been identified (6). The CIN phenotype is characterized by aneuploidy and chromosomal gains and losses, the MSI phenotype exhibits the presence of frequent insertion and deletion mutations in repetitive DNA sequences and the CIMP phenotype shows patterns of aberrant gene methylation (6). The challenge is to improve treatment of CRC patients with stage III and IV disease. Presently, folfox (5-FU, leucovorin, oxaliplatin, cape ox (capecitabin, oxaliplatin), folfiri (leucovorin, 5-FU, irinotecan) or folfoxiri (leucovorin, 5-fu, oxaliplatin, irinotecan) are used as standard therapy with limited success in advanced disease (7). Also, combinations of chemotherapy with angiogenesis-targeting agents, such as bevacizumab, ramucirumab and aflibercept or epidermal growth factor receptor (EGFR)-targeting monoclonal antibodies (mABs) such as cetuximab and panitumab have been approved (7). Immunotherapy with antibodies disrupting the programmed cell death protein 1 (PD1) and PD-1 ligand (PD-1L) immune checkpoint, such as nivolumab and pembrolizumab, looks promising, especially in patients with the MSI subype, however, the results have to be verified in large randomized studies $(8,9)$.

In order to define new targets and treatment modalities for patients with metastatic CRC we have summarized miRs 
and corresponding targets, which modulate metastasis in in vivo models.

\section{Metastasis of CRC}

Metastasis of CRC is a multi-step process involving local invasion, intravasation, activation of mechanisms allowing survival in the circulation, arrest at distant organ sites, extravasation, formation of micro-metastases and finally their outgrowth and colonization of distant organs (10). At the time of diagnosis, $20 \%$ of CRC patients have already developed metastatic disease (11). CRCs most commonly metastasize to the liver, lungs and peritoneum, but also various other sites such as bone, spleen, brain and distant lymph nodes have been described (12-15). More than 50\% of patients with CRC will develop metastases to the liver over the course of their life, which ultimately results in death of more than two thirds of these patients (16). CRC preferentially metastasizes to the liver. This can be explained by a trapping mechanism of CRC cells in the mesenteric circulation in the liver $(17,18)$. However, other mechanisms may play a role such as preferred outgrowth of CRC cells in the liver due to premetastatic niche formation based on the "seed and soil hypothesis" $(19,20)$. This hypothesis postulates that a target organ is susceptible due to circulating signaling factors or factors packed into exosomes $(19,20)$. It has been found that liver metastases are formed before lung metastases are established (21). Recent sequencing of primary colorectal tumors and matching liver metastases revealed heterogeneity of metastases and metastasis-specific mutations leading to activation of phosphoinositide 3-kinase (PI3K)-AKT signaling, cell adhesion and extracellular matrix as well as induction of hepatic stellate activation genes (22).

\section{miRs and Their Role in Oncology}

miRs are transcribed in the nucleus by RNA polymerase II as primary miR transcripts (pri-miRs) which are subsequently cleaved by the microprocessor complex to produce $30 \mathrm{bp}$ comprising short hairpin RNAs (shRNAs) referred to as pre-miRs $(23,24)$. Subsequently, exportin 5 binds to the pre-miRs and transports them to the cytoplasm $(23,24)$. After cleavage of the pre-miRs by DICER, an RNA-induced silencing complex (RISC)-loading complex is formed, a guide strand (antisense) is selected and the passenger strand (sense) is discarded (25). RISC can regulate mRNA expression by pairing with the 3'-untranslated region (3'-UTR) of the target mRNA and inducing cleavage of the mRNA and/or inhibition of its translation (25). miRs have many targets and are partially complementary to the 3'-UTR of their target mRNAs in contrast to siRNAs which are fully complementary to the coding region of their mRNA targets (26). miRs can interfere with several pathways because they can target hundreds of mRNAs and therefore have the potential to rewire the oncogenic and metastatic state (27). Tumor-suppressive functions have been demonstrated first for miRs-15a and miR-16-1 in the context of pathogenesis of B-cell chronic lymphatic leukemia (B-CLL) (28-30). Deletion of the locus harboring miRs $15 \mathrm{a}$ and -16-1 in mice recapitulated the B-CLL phenotype (28-30). These miRs mediate the cleavage of B-cell lymphoma 2 (BCL2), which functions as an anti-apoptotic protein (28-30). We have recently summarized the functional contribution of miRs to metastasis of ovarian, breast, prostate and lung cancer (3134). In this review, we focus on miRs involved in metastasis of CRC with documented in vivo activity in metastasisrelated models.

\section{miRs Up-regulated in Metastatic Colon Cancer Cells}

miRs targeting tumor and metastasis suppressor mRNAs. miR-15b increases invasion and migration of CRC cell line HCT-116 and intrasplenic injection of HCT-116 cells transfected with anti-miR-15b exhibits decreased number of metastatic nodules in the liver of nude mice (35). Metastasissuppressor 1 (MTSS1) and klotho were identified as direct targets of miR-15b (Figure 1). MTSS1 is a multi-functional protein, which functions as a tumor suppressor (TS) and inhibitor of metastasis (36). Klotho is a transmembrane protein and TS which acts as a co-receptor for fibroblast growth factor (FGF) receptors, modulates $\mathrm{WNT} / \beta$-catenin signaling and suppresses metastasis of renal cancer xenografts in mice (37-39). High plasma levels of miR-15b in CRC patients are associated with local recurrence, distant metastases and poor prognosis (35).

miR-103/107 (Figure 1) increases motility and invasiveness of HCT-116 CRC cells and overexpression of miR103/107 in HT-29 and HCT-116 cells promotes cell matrix adhesion and inhibits cell-cell adhesion (40). HCT-116 cell transfected with miR103/107 expression vectors exhibit significantly increased size and number of metastatic nodules in the liver after implantation into the caecum of nude mice (40). Deathassociated protein kinase (DAPK) and krüppel-like factor 4 (KLF4) were identified as direct targets of miR-103/107 (40). DAPK acts as a TS and inhibits cell-matrix adhesion by inactivation of integrin $\beta 1$ and interferes with cell migration (41). DAPK also has been identified as a suppressor of CRC metastasis $(42,43)$. The other target, KLF4, is a zinc finger transcription factor, which suppresses tumor formation in genetic and pharmacological mouse models of colonic tumorigenesis (44). From a clinical point of view, a signature of miR-103/107 high, DAPK low and KLF4 low, correlates with metastasis and poor prognosis in CRC patients (40).

miR-182 (Figure 1) accelerates growth, invasion and migration of CRC cell line SW480 in vitro (45). SW480 cell transfected with miR-182 and subcutaneously implanted into 


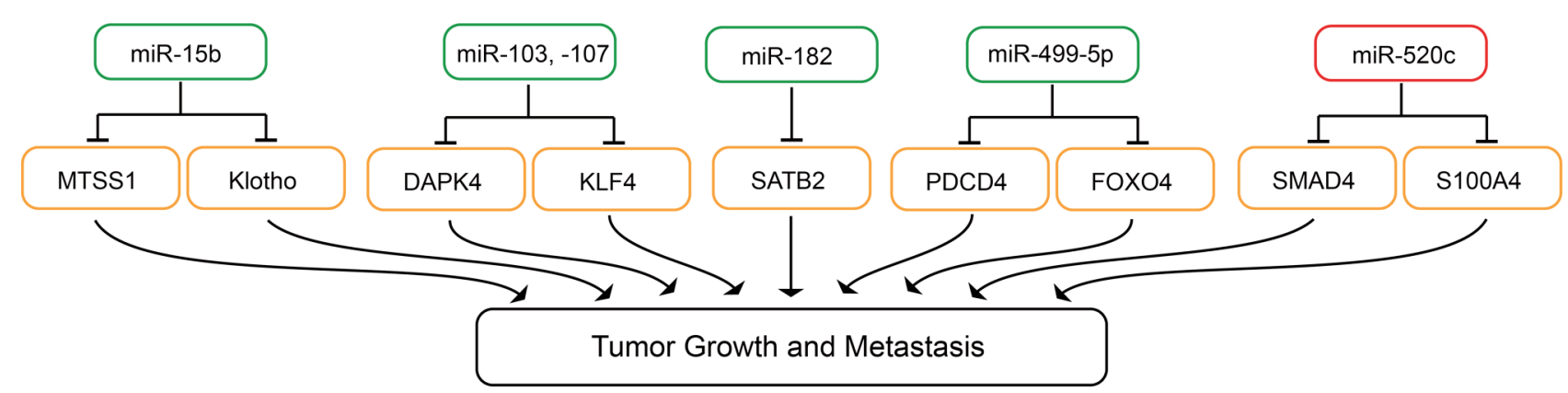

Figure 1. miRs modulating tumor- or metastasis-suppressor genes with efficacy in metastasis-related colocrectal cancer in vivo models. miRs upregulated in CRC biopsies are boxed in green, downregulated miRs are boxed in red. The corresponding targets are boxed in yellow. DAPK: Death asscociated protein kinase; FOXO4: forkhead bOX protein 04; KLF4: krüppel-like factor 4; Klotho: transmembrane protein klotho; MTSS1: metastasis suppressor 1; PDCD4: programmed cell death protein 4; S100A4: S100 binding protein 4; SATB2: special AT-rich sequence binding protein; SMAD4: mothers against decaplegic homolog 4.

nude mice exhibit increased metastasis to the abdominal cavity, liver, lymph nodes and lungs (45). Special AT-rich sequence binding protein 2 (SATB2), a member of the nuclear matrix attachment proteins that recognize AT-rich sequences at the base of looped-out chromatin, was identified as a target of miR-182 $(45,46)$. SATB2 is mainly expressed in epithelial cells of colon and rectum and in the nuclei of neurons in the brain (47). SATB2 is down-regulated in CRC patients with metastasis and poor prognosis (48). miR-182 is highly expressed in CRC patients with metastasis compared to patients without metastases (45).

miR-499-5p (Figure 1) transfectants of the SW480 CRC cell line show increased migration and woundhealing in comparison to control cells (49). After tail vein injection of miR-499-5p transfectants of SW480 cells into nude mice, number and size of lung and liver metastatic nodules were increased in comparison to the untransfected cell line (49). As direct targets, forkhead box protein O4 (FOXO4) and programmed cell death protein 4 (PDCD4) have been identified (49). FOXO4 is a transcription factor which suppresses functions downstream of PI3K/AKT $(50,51)$. The other target, PDCD4, has been identified as a TS, which inhibits proliferation, cell-cycle progression and induces apoptosis (52). In colon cancer cells, down-regulation of PDCD4 promotes invasion and activates $\beta$-catenin/transcription factor seven 7 (TCF7) and activator protein 1 (AP1)-dependent transcription in colon carcinoma cells (53). In CRC, PDCD4 reduces zincfinger protein SNAIL, up-regulates E-cadherin, down-regulates transcription factor c-MYC and urokinase plasminogen activator receptor (UPAR), inhibits mTOR complex 2 (mTORC2) and decreases interleukin 6 (IL6), tumor necrosis factor $\alpha(\mathrm{TNF} \alpha)$ and nuclear factor $\mathrm{kB}$ (NFkB) (54). miR-499$5 \mathrm{p}$ expression in CRC is associated with clinical stage and lymph node metastasis (49). miRs interfering with signaling are shown in Figure 2.
miRs inducing EMT. miRs-135b and -210 (Figure 3B) both seperately and in combination induce migration and invasion of RKO and HCT-116 CRC cells in vitro (55). RKO and HCT-116 cells transfected with miR-135 or miR-210 exhibit enhanced metastasis to lungs and liver after injection into chicken embryos (55). Seven in absentia homolog1 (SIAH1), set domain containing 2 (SETD2) and forkhead box protein N 3 (FOXN3) were identified as targets for both, miR-135b and miR-210 (55). SIAH1 functions as an E3 ubiquitin ligase, which induces proteasome-mediated degradation of specific proteins (56). SETD2 is a histone methyltransferase specific for lysine-36 of histone $\mathrm{H} 3$ which is involved in transcriptional regulation, chromatin regulation, DNA repair and splicing (57). FOXN3 suppresses N-Cadherin, a transmembrane receptor involved in EMT (58). miR-135 and -210 and their targets are reciprocally expressed in CRC tissues (55).

miR-181a (Figure 2) stimulates growth, invasion, migration and induces EMT of HT-29 CRC cells in vitro (59). HT-29 cells transfected with miR-181a give rise to increased liver metastasis after implantation into the spleen of nude mice (59). WNT inhibitory factor-1 (WIF-1) has been identified as a target of miR-181a (59). WIF-1 is a lipid binding protein, which binds to WNT proteins and prevents them from triggering signaling (60). WIF-1 was shown to be down-regulated in prostate, breast, lung and bladder cancer and restauration of expression of WIF-1 reversed EMT, invasion and tumor growth $(61,62)$. Elevated expression of miR-181a in CRC samples correlates with advanced clinical stage, distant metastasis and serves as an independent prognosis marker for poor survival (60).

miR-196a-5p (Figure 3B) promotes proliferation of SW480, SW620 and HCT-116 CRC cells (63). After implantation into the spleen, SW480 cells transfected with miR-196a-5p exhibit more liver metastases than the control cell line, whereas its 

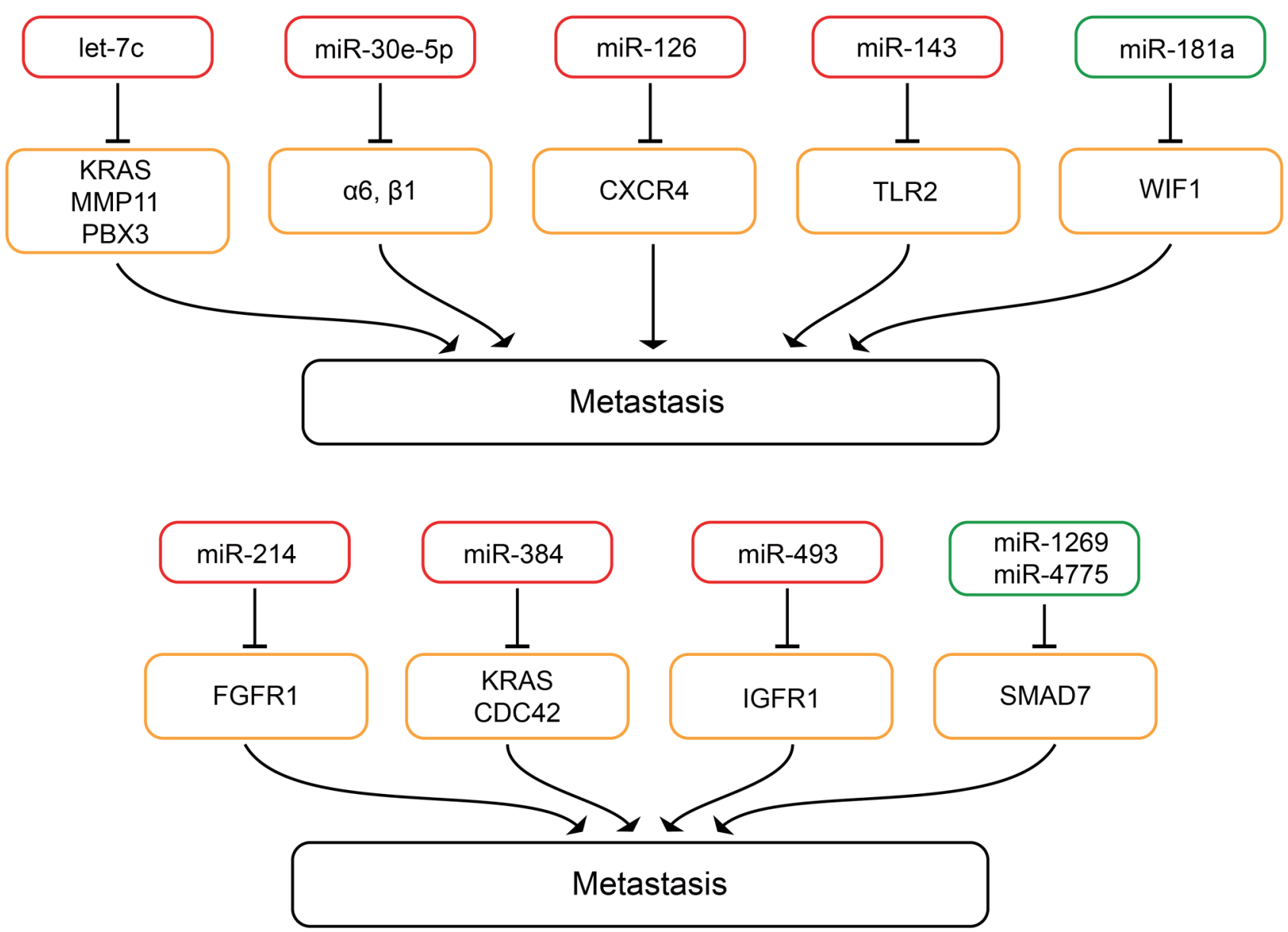

Figure 2. miRs modulating signaling pathways with efficacy in metastasis related colocrectal cancer in vivo models. miRs up-regulated in CRC biopsies are boxed in green, downregulated miRs are boxed in red. The corresponding targets are boxed in yellow. $\alpha 6, \beta 1:$ Integrin $\alpha 6, \beta 1 ; C D C 42$ : cell division control protein 42 homolog; CXCR4: C-X-C chemokine receptor 1; FGFR1: fibroblast growth factor receptor 1; IGFR1: Insulin-like growth factor receptor 1; KRAS: kirsten ras; MMP11: matrix metalloproteinase 11; PBX3: pre-B-cell leukemia transcription factor X3; SMAD7: mother against decapledgic homolog 7; TLR2: toll like receptor 2; WIF1: WNT-Inhibitory factor 1.

knock-down in HCT-116 cells attenuates liver metastasis (63). miR-196a-5p promotes EMT transition in CRC cells accompanied by down-regulation of E-cadherin and upregulation of N-cadherin and fibronectin (63). Nuclear factor of kappa light polypeptide gene enhancer in B-cells inhibitor $\alpha(\operatorname{IkB} \alpha)$, a negative regulator of $\mathrm{NFkB}$ signaling was identified as a target of miR-196a-5p (63). IkB $\alpha$ blocks the ability of NFkB transcription factors to bind to DNA (64). Data addressing correlations of expression of miR-196a-5p and clinical parameters of patients with CRC are not available yet.

miR-544a (Figure 3B) mediates invasion of HCT-116 and SW480 CRC cells (65). Inhibition of miR-544a transfected HCT-116 cells leads to reduction of lung metastasis of subcutaneously implanted cells in comparison to control cell lines (65). The mRNA of homeobox gene HOXA10 has been identified as a target of miR-544a (65). Overexpression of
HOXA10 leads to up-regulation of E-cadherin, a validated inhibitor of EMT (65-67). Expression of miR-544a in CRC tissues correlates with metastatic propensity (65).

miR-885-5p (Figure 3B) expression induces cell migration in HCT-116 and DLD-1 cells through activation of EMT (68). miR-885-5p enhances stressfiber formation through rearrangement of the cytoskeleton (68). HCT-116 cells transfected with miR-885-5p give rise to increased liver and lung metastasis after orthotopic implantation into the caecum (68). Cytoplasmic polyadenylation element binding protein 2 (CPEB2) has been identified as a target of miR-885-5p (68). CEBP2 is a negative regulator TWIST, a transcription factor involved in EMT (69-71). miR-885-5p is overexpressed in liver metastases of CRC patients (68).

miRs-1269a and -4775 (Figure 2) activate transforming growth factor $\beta$ (TGF $\beta$ ) signaling $(72,73)$. Ectopic 



B

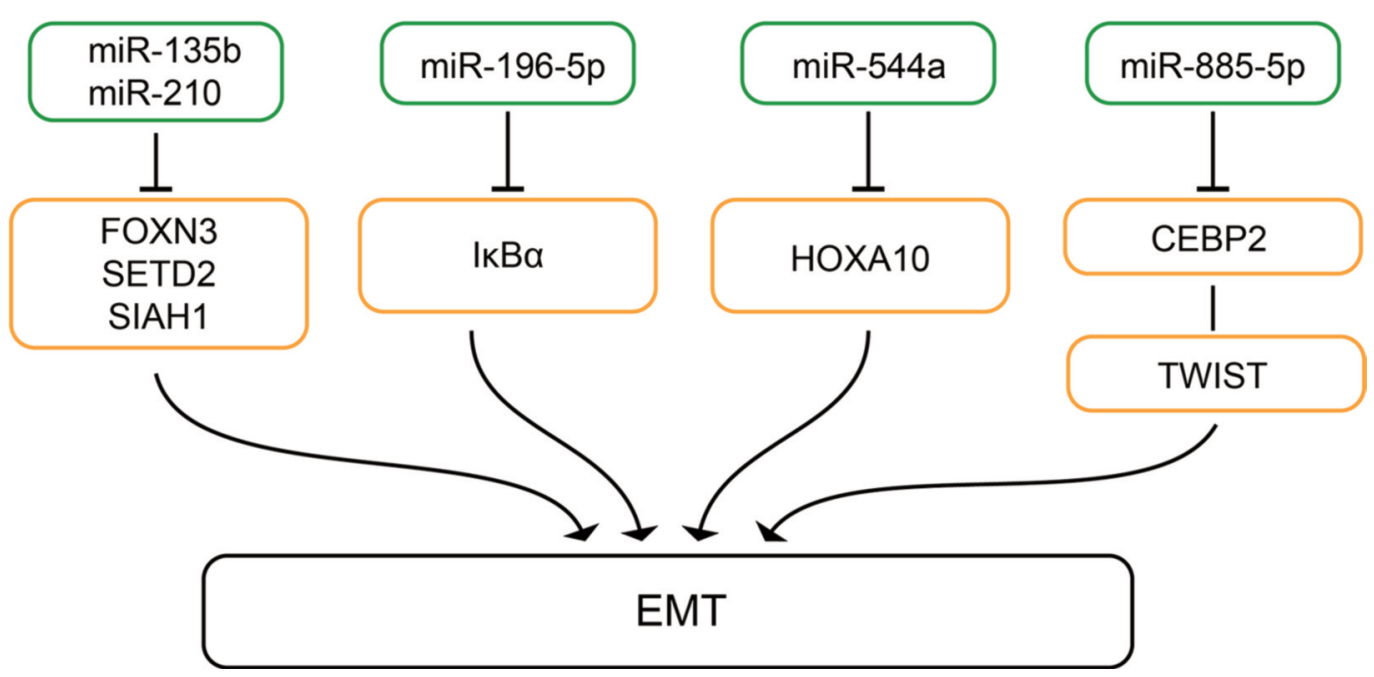

Figure 3. miRs modulating epithelial-mesenchymal transition with efficacy in metastasis-related colocrectal cancer in vivo models. Down-regulated miRs are boxed in red, up-regulated miRs in green, targets are boxed in yellow. A: miRs 15a/16-1, -30c, -34a, -192, -335, -200b-3p, -212, -218 and -374a. B: miRs 135b, -210, -196a-5p, -544a and -885-5p. ADAM19: A disintegrin and metalloproteinase 19; AP4: activating enhancer binding protein 4; BCL2: B-cell lymphoma 2; CCND1: cyclin D1; CEBP2: cytoplasmic polyadenylation element binding protein; FOXN3: forkhead box protein N3; HOX A10: homeobox gene HOX A10; IL-6R: interleukin 6 receptor; IkBa: nuclear factor of $\kappa$ light chain polypeptide gene enhancer in B cells Inhibitor $\alpha$; MnSOD: manganese superoxide dismutase; N-cadherin: neural cadherin; PRDX2: periredoxin 2; SETD2: set domain containing 2; SIAH1: seven in absentia homolog 1; TWIST: transcription factor TWIST; ZEB2: zinc finger E-box binding homeobox 1 . 
expression of miR-1269a and -4775 increases migration of SW480 and SW620 CRC cells (72, 73). SW480 cells transfected with miR-1269a and implanted into the caecum give rise to increased metatases to the liver. After tail vein injection of the transfectants, metastases to the lungs and the liver are increased (72). Overexpression or knocking-down of miR-4775 in SW480 or SW620 cells increases or decreases lung and liver metastasis after injection into the tail vein of nude mice (73). Both of them are inducers of EMT and target mothers against decapentapledgic homolog 7 (SMAD7). miR$1269 \mathrm{a}$ in addition targets the mRNA of homeobox gene HOXD10 (72, 73). SMAD7 inhibits TGF $\beta$ signaling which is induced by interaction of heterodimeric transmembrane serine/threonine kinase complexes, including transforming growth factor $\beta$ receptor I and II (TGF $\beta$ RI and TGF $\beta$ RII) with cytokines $(74,75)$. SMAD7 blocks receptor-regulated SMAD (R-SMAD) phosphorylation by occuping the catalytic domain of TGFR $\beta$ I. Inhibition of SMAD7 leads to activation of R-SMADs through TGF $\beta$ RI. Activated R-SMADS (pSMAD2 and pSMAD3) form a complex with SMAD4 which translocates into the nucleus and regulates transcription of specific target genes $(75,76)$. The role of TGF $\beta$ signaling in the pathogenesis of CRC is well documented (77). Elevated TGF $\beta$ production is associated with the risk of CRC relapse and metastases (77). Both, miR-1269a and -4775 are upregulated in $\mathrm{CRC}$ tissues, correlate with $\mathrm{CRC}$ progression and are indicators of poor survival in CRC patients $(72,73)$.

\section{miRs Down-regulated in Metastatic Colon Cancer Cells}

miRs targeting KRAS. miRs-let-7c and -384 (Figure 2) target KRAS $(78,79)$ (Figure 3$)$. KRAS is a member of the small GTPase super-family and is constitutively activated by mutation of a single amino acid and is one of the early oncogenic drivers in CRC with a prevalence of $40 \%$ in this type of tumor $(80,81)$. miR-let-7c in addition targets matrix metalloproteinase 11 (MMP11) and pre-B-cell leukemia transcription factor 3 (PBX3) (80). Expression of MMP11, also known as stromelysin 3, correlates with the aggressiveness of CRC (82). PBX3 is a homeobox gene which is part of the EMT regulatory network and indicates poor outcome in patients with CRC (83). In addition to KRAS, miR-384 directly targets cell division control protein 42 homolog (CDC42), a member of the RHO family of GTPases. miR-384 is involved in cell-cycle progression, actin filopodia formation and migration (84). miRs-let-7c and -384 inhibit migration of LoVo and SW620 cells in vitro $(78,79)$. Over-expression of let-7c in LoVo cells inhibits growth and metastasis in the chorioallantoic model (CAM) (78). Inhibition of miR-384 in LoVo and SW620 results in more hepatic metastases after intrasplenic injection (79). Decreased expression of miR-let-7c is associated with metastasis in CRC patients (78). miR-384 is down-regulated in CRC biopsies in comparison to adjacent normal tissue and is closely associated with aggressive characteristics of CRC (79).

miRs targeting transmembrane receptors. miR-30e-5p (Figure 2) overexpression reduces cell adhesion and migration of CRC cells RKO and HCT-116 in vitro (85). In RKO and HCT-116 cells miR-30e-5p overexpression decreases tumor weight and metastasis in the CAM assay (85). Integrins $\alpha 6$ and $\beta 1$ (INT $\alpha 6$ and INT $\beta 1$ ) have been identified as direct targets of miR-30e-5p (85). miR-30e-5p suppresses the adhesion of INT $\alpha 6$ in CRC cells to laminin (85). miR-30e5 p induces p21 and p27 inhibitors of cell-cycle progression (85). The anti-metastatic effects of INT $\alpha 6$ and INT $\beta 1$ are due to inhibition of adhesion to ECM, migration, invasion and proliferation $(85,86,87)$. miR-30e-5p is down-regulated in tumors of $\mathrm{CRC}$ patients in comparison to corresponding normal tissues (85).

miR-126 (Figure 2) inhibits subcutaneous growth of HCT116 and SW480 CRC cells and decreases lung metastasis of these cells after tail vein injection (88). miR-126 targets C$\mathrm{X}-\mathrm{C}$ chemokine receptor type 4 (CXCR4) and Ras homolog gene family, member A (RHO A) signaling pathway components in human CRC cells (88). CXCR4-G13 RHO signaling has been shown to drive transendothelial migration of breast cancer cells (89). Overexpression of CXCR4 and its ligand stromal-derived factor 1 (SDF-1) correlates with dissemination and reduced overall survival in patients with gastrointestinal tumors $(90,91)$.

miR-143 (Figure 2) reverses the invasive and migratory phenotype of CRC cells SW620 and HCT-116 (92). miR-143 overexpression in SW620 CRC cells significantly decreases lung colonization after tail vein injection in nude mice (92). Toll-like receptor 2 (TLR2) has been identified as a direct target of miR-143, indicating a novel pathway that controls CRC cell invasion and migration (92). Also, TLR2-dependent inflammation plays an important role in metastatic progression (93). TLRs play a critical role in innate immunity and subsequent induction of the adaptive immune response $(94,95)$. Low levels of miR-143 are associated with advanced pathology stages of CRC and lymph node metastasis (92).

miR-214 (Figure 2) transfected HCT-116 and LoVo cells exhibtit significantly slower growth rate and markedly reduced migration and invasion (96). Ectopic expression of miR-214 in HCT-116 cells mediates significant reduction of metastatic nodules in the liver after intrasplenic implantation (96). Fibroblast growth factor receptor 1 (FGFR1) has been identified as a direct target of miR-214 (96). FGFR1 is a member of the FGFR kinase family that contains four transmembrane tyrosine kinases (97). FGFR1 inhibition prevents liver metastasis of colon xenografts by modulating the pre-metastatic niche. Expression of FGFR1 in CRC patients is associated with metastasis $(98,99)$. 
miR-493 (Figure 2) inhibits liver metastasis of HCT-116 cells after injection into the spleen of nude mice (99). miR493 expression induces cell death of HCT-116 cells in colonized liver parenchyma (99). Insulin-like growth factor receptor1 (IGFR1) was identified as a direct target of miR493 (99). IGFR1 promotes survival and metastasis of several types of cancer including CRC $(100,101)$.

miRs targeting EMT-related mRNAs. The miR-15a/16-1 (Figure 3A) cluster is hosted by the DLEU2 gene which is frequently deleted or down-regulated in human tumors (102). EMT-inducing transcription factor activating enhancer binding protein 4 (AP4) is the target of the p53-inducible miRs-15a/16-1 $(102,103)$. AP4 has similar functions as other EMT mediators such as zinc finger proteins SNAIL and SLUG, zinc finger E-box-binding homeobox 1,2 (ZEB1, ZEB2), TWIST and MYC (104, 105). AP4 forms a doublenegative feedback loop with miR-15a/16-1 (106). SW620 CRC cells transfected with miR-15a/16-1 exhibit decreased lung colonization after tail vein injection (106). An inverse correlation between expression of AP4 and miR-15a/16-1 has been noted in primary CRC (106).

miR-30c (Figure 3A) inhibits proliferation, invasion, migration and EMT of CRC cells (HCT-116, LoVo and SW620) (107). HCT-116 cells transfected with miR-30c show a decrease in tumor size after subcutaneous implantation into nude mice and inhibition of lung colonization after tail vein injection (100). ADAM19 was identified as a direct target of miR-30c (107). A disintegrase and metalloproteinase 19 (ADAM19) is involved in promotion of invasiveness of tumors by degradation of components of the ECM and has been shown to be up-regulated in renal carcinoma and brain tumors (108-110).

IL6 induces EMT and invasion of CRC cells, such as DLD-1. This phenomenon is mediated by repression of miR-34a (Figure 3A) by signal transducer and activator of transcription 3 (STAT3) (111). DLD-1 cells treated with IL6 ex vivo exhibit lung colonisation after tail vein injection into nude mice (111). IL-6R has been identified as a direct target of miR-34a (111). Down-regulation of STAT3 or IL-6 receptor (IL-6R) by small interfering RNA (siRNA) in SW620 CRC cells suppresses lung metastasis in nude mice after tail vein injection (111). An IL6R/STAT3/miR-34a feedback loop is manifest in carcinoma cell lines with mesenchymal characteristics and activation of this feedback loop is associated with metastasis of CRC (111). In a mouse model of colitis-associated CRC cancer, induced by azomethane and dextran sulfate (112), knockout of miR-34a results in invasive tumors that penetrate through the muscularis mucosa and may ultimately result in metastasis (111). Activation of IL6/IL6R pathway can lead to metastasis and inhibition of the IL6/IL6R/STAT3 pathway has been shown to inhibit CRC growth and metastasis $(113,114)$.
miRs targeting ZEB2. miRs-192, -218 and -335 (Figure 3A) target ZEB2, miR-218 also targets N-cadherin and miR-335 in addition to ZEB2 targets BCL2 directly and vascular endothelial growth factor-A (VEGF-A) indirectly $(55,115$, 116). In an orthotopic mouse model, HCT-116 cells transfected with miR-192 exhibited sixfold reduction of incidence of liver metastasis, whereas growth of primary tumors after subcutaneous implantation was only modestly affected (115). Nude mice injected with SW620 cells expressing miR-218 into the tail vein live significantly longer than animals injected with control cells (55). miR-218 transfected SW620 cells also exhibit reduced ability to metastasize into the lungs and liver of chicken embryos (55). SW620 cells transfected with miR-335 show a decrease of lung and liver metastases after tail vein injection (116). ZEB2 is a member of the homeodomain transcription factors with 9 zinc fingers and one homeodomain (117). ZEB-2 binds to regulatory gene sequences at E-boxes and functions as a transcriptional activator and repressor by inhibition of epithelial genes and activation of mesenchymal genes (117). In CRC, induction of EMT functions as a culprit of metastases (118). EMT-related functions of ZEB-2 are mediated by its interaction with R-SMAD, an effector of TGF $\beta$ signaling (119). It has been shown previously that silencing of ZEB-2 by siRNA decreases migration and invasion of CRC cell lines (120). EMT enables CRC cells to migrate through the ECM and colonize lymph/blood vessels, thereby initiating the first step of the metastatic cascade (121). For miR-192 an inverse relationship between miR-192 expression and ZEB-2, BCL2 and VEGF-A in CRC biopsies has been detected (115). Reduced expression of miR-218 has been noted in CRC biopsies in comparison to corresponding normal tissues (56). Low expression of miR-335 is associated with shorter survival in CRC patients (116).

miRs targeting redox-related miRs. miR-200b-3p (Figure 3A) inhibits growth of LoVo CRC cells transfected with miR200b-3p after subcutaneous implantation and metastasis to the liver in an orthotopic model with this cell line (122). miR200b-3p inhibits EMT and is inhibited by c-MYC (122). Periredoxin 2 (PRDX2), an antioxidant enzyme which reduces peroxides, has been identified as a target of miR200b-3p (122, 123). It has been shown that PRDX2 silencing contributes to metastasis due to decreased c-MYC expression by down-regulating WNT/ $\beta$-catenin signaling (124). Furthermore, miR-200b-3p disrupts c-MYC protein stability through inhibition of the AKT2/ glycogen synthase kinase $3 \beta$ (GSK3 $\beta$ ) pathway (122). miR-200b-3p is down-regulated in metastatic CRC cell lines and CRC biopsies compared to their normal counterparts (124).

Ectopic expression of miR-212 (Figure 3A) inhibits EMT transition in HCT-116 and SW480 cells (125). Liver metastasis of these cells is inhibited after injection into the 
spleen of nude mice (125). Manganese superoxide dismutase (MnSOD) has been identified as a direct target of miR-212 (125). MnSOD is a mitochondrial anti-oxidant enzyme which dismutates superoxide radicals into either oxygen or hydrogen peroxide and protects CRC cells from tumor necrosis factor related apoptosis inducing ligand (TRAIL)-induced apoptosis. Furthermore, SOD promotes anoikis resistance and tumor metastasis $(126,127)$. It was hypothesized that overexpression of MnSOD in CRC cells leads to a greater hydrogen peroxide flux which leads to accumulation of hypoxia-inducible factor- $1 \alpha$ (HIF-1 $\alpha$ ) which in turn confers EMT traits to CRC cells (128). HIF-1 $\alpha$ can induce aggressive malignant traits in tumor cells independent of its canonical transcription factor function (129). Low level of miR-212 expression is associated with an aggressive and poor prognostic phenotype in CRC patients (56).

miRs targeting cell-cycle related proteins. miR-374a (Figure $3 \mathrm{~A})$ inhibits proliferation and invasion of miR-374a transfected HCT-116 cells (130). Subcutaneously implanted SW620 cells transfected with miR-374a give rise to markedly smaller tumors and fewer metastasis after intrahepatic injection (130). miR-374a decreases EMT-markers such as N-Cadherin, ZEB1, vimentin, SLUG and TRAIL (130). Cyclin D1 (CCND1) was identified as a direct target of miR-374a (130). CCND1 has been shown to suppress the PI3K/AKT pathway (130). PI3K/AKT pathway can promote EMT transition $(131,132)$. CCND1 forms a complex and functions as a regulatory subunit of cyclin-dependent kinases 4 and 6 (CDK4 and CDK6) which are required for cell-cycle G1/S transition $(131,132)$. High miR-374a with a low level of CCND1 expression correlates with a good prognosis in CRC patients (130).

miRs targeting other mRNAs. miR-22 (Figure 4) suppresses cell proliferation, colony formation, migration and invasion of CRC cell lines SW620 and LoVo (133). Subcutaneously implanted SW620 cells transfected with miR-22 exhibit decreased cell growth in comparison to the control cell line. Tail vein injection of these cells give rise to reduced numbers and size of lung nodules (133). Specificity protein 1 (Sp1) has been identified as a direct target of miR-22 (133). Sp1 is a member of the transcription factor family, promotes growth, migration and invasion of CRC cells and plays an important role in CRC development and progression $(134,135)$. miR22 suppresses the phosphatase and tensin homolog (PTEN)/AKT pathway by targeting Sp1 expression (133). PTEN is a key tumor suppressor that antagonizes the $\mathrm{PI} 3 \mathrm{~K} / \mathrm{AKT}$ pathway, which is highly involved in CRC cancer progression (136-138). From a mechanistic point of view, Sp1 can inhibit PTEN expression by binding to the PTEN promoter region (139). Down-regulation of miR-22 is associated with disease progression and metastasis in CRC patients (133).

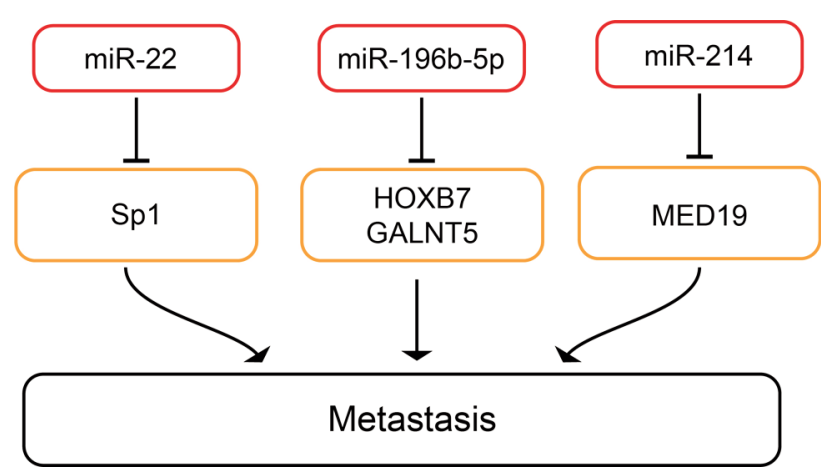

Figure 4. miRs modulating other targets with efficacy in metastasisrelated colocrectal cancer in vivo models. Down-regulated miRs are boxed in red, targets are boxed in yellow. GALNT5: Polypeptide Nacetylgalactosaminyltransferase 5; HOXB7: homeobox protein B7; MED19: mediator 19; Sp1: specificity protein 1.

miR-196b-5p (Figure 4) inhibits proliferation and invasion of a panel of 8 CRC cell lines and its inhibition in HCT-116 CRC cell line inhibits intra-abdominal metastasis (140). Homeobox protein B7 (HOX B7) and N-acetylgalactosaminyltransferase 5 (GALNT5) have been identified as targets of miR-196b-5p (140). Transcription factor HOX B7 promotes proliferation and tumorigenic growth of human CRC cells both in vitro and in vivo (141). GALNTs are involved in modulating ECM composition and affecting cell adhesion and numerous pathways in tumor formation and cancer progression (142). Low levels of miR-196b-5p in CRC biopsies correlate with bad prognosis (140).

miR-214 (Figure 4) inhibits proliferation and invasion of six CRC cell lines and its expression is up-regulated by forkhead box P3 (FOXP3) (143). In vivo, SW480 cells transfected with miR-214 give rise to fewer and smaller lung metastatic nodules after tail vein injection in comparison to the control cell line (143). miR-214 directly targets mediator 19 (MED19), a component of the mediator complex (143). Mediator is a multiprotein complex, which transmits signals from transcription factors to RNA polymerase II and directly interacts with these components $(144,145)$. The role of mediator components MED1 MED12, MED28, cyclin C and cyclin-dependent kinase 8 (CDK8) in malignancy are well documented (145). MED19 binds to gene-specific regulatory factors and provides support for the basal RNA polymerase II activity and its inhibition decreases growth of hepatocellular carcinoma, prostate cancer and osteosarcoma cell lines (146-149). With respect to clinical correlations of miR-214, it was found to be down-regulated in CRC biopsies and to be correlated with lymphatic metastasis, probably by promoter hypermethylation (143).

miR-520c (Figure 1) significantly inhibits migration and invasion of HCT-116 and SW620 cells and targets S100 
calcium-binding protein A4 (S100A4) (150). Intrasplenic injection of HCT-116 cells transfected with miR-520c results in reduction of TG and liver metastases in comparison to the control cell line (150). S100A4 is a member of the S100 calcium binding protein family which interacts with receptor of advanced glycation end products (RAGE) and has been classified as a metastasis-related protein which is also referred to as metastasin (151-153). S100A4 is an activator of proliferation and invasion-promoting WNT signaling (154). Furthermore, S100A4 promotes metastasis by interaction with myosin and as a promoter of angiogenesis $(155,156)$. S100A4 has been identified as a prognostic marker for poor survival of CRC patients $(157,158)$. An important clinical aspect is down-regulation of miR-520c in CRC biopsies due to hypermethylation of its promoter region (150).

\section{Therapeutic Aspects}

Recent studies have identified several targets for treatment of CRC-related liver metastasis (17). Apoprotein B mRNA editing enzyme 3G (APOBEC 3G), cluster of differentiation 133 (CD133), chemokine receptor 4 (CXCR4), L1 cell adhesion molecule (L1 CAM), lipase C (lipase C), metastasis associated in colon cancer-1 (MACC1), hepatocyte growth factor (HGF) and tyrosine kinase MET (c-MET), phosphatase of regenerating liver 3 (PRL3), tumor-associated signal transducer 2 (Trop-2), S-family proteins S100A4 and S100 P and notch receptors are targets under preclinical and clinical evaluation for treatment of CRC-related liver metastasis (17). In order to extend this panel of targets, we surveyed the literature for miRs, which modulate formation of CRC-related metastasis to distant organs.

We have identified 12 up-regulated and 19 down-regulated miRs conferring in vivo efficacy in CRC-related models. The vast majority of identified miRs $(n=16)$ contributes to modulation of EMT. ZEB2 as a single target or in combination with BCL2 or N-Cadherin is targeted by miRs $192,-218$ and -335 and is the most prevalent target in the EMT-related category. ADAM19, IkB $\alpha$, FOXN3, HOXA10, AP4, CEBP2, IL6R, CCND1, PRDX2, MnSOD, SETD2 and SIAH1 were identified as further EMT-modulating targets. Noteworthy, PRDX2 and MnSOD are proteins with antioxidative function. Inhibition of proteins, which negatively affect signaling pathway by miRs is another theme emerging from survey of the literature. Examples of EMT-related targets are WIF-1 (miR-181a), an inhibitor of WNT/ $\beta$-catenin signaling and SMAD7 (miR-1269a and -4775), an inhibitor of TGF $\beta$ signaling. A further category of identified miRs affects tumor- or metastasis suppressing mRNAs such as MTSS1 and Klotha (miR-15b), DAPK4 (miRs-103, -107), SATB2 (miR-182), PDCD4 (miR-499-5p) and S100A4 (miR$520 \mathrm{c}$ ). Another subclass of identified miRs promotes or interferes with signaling pathways such as KRAS which is mutated in $40 \%$ of CRC. KRAS is inhibited by miRs let-7c and -384. Another subclass of identified miRs target transmembrane tyrosine kinse receptors such as FGFR1 (miR-214) and IGFR1 (miR-493). Further signal-transducing recptors identified by our survey are intrgrins $\alpha 6$ and $\beta 1$ (miR-30e-5p), CXCR4 (miR-126) and TLR2 (mi-143). Other identified targets do not match with the target categories as described above. These are Sp1 (miR-22), HOXB7 and GALNT5 (miR-196b-5p) and MED19 (miR-214). Depending on the context, miR-196-5p can mediate EMT by targeting $\mathrm{IkB} \alpha$ (Figure $3 \mathrm{~B}$ ) or metastasis by targeting HOXB7 and GALNT5 (Figure 4).

With respect to therapeutic intervention, up-regulated miRs are candidates for inhibition of function and down-regulated miRs are candidates for reconstitution of function. miRinhibitors are referred to as antagomirs and are singlestranded RNA molecules in the range of 12-25 nucleotides complementary to the target mRNA or miR sponges that are constructs with multiple reiterated miR binding sites which compete with the natural mRNA target for binding to the corresponding miR (23-25). The alternative therapeutic option, functional reconstitution of corresponding miRs, can be performed with miR mimetics, small double-stranded RNAs designed to mimic endogeneous mature miRs (23-25). Alternarively, miR function can be reconstituted through expression of the corresponding miR by appropriate vectors or small double-stranded RNA mimetics (23-25). Since the approaches for identification of miRs involved in metastasis of CRC rely on very similar methods and neither inhibition or reconstitution of identified miRs has been translated into clinical studies, a prioritization of their therapeutic potential is presently not possible. The same holds true for their cognate targets. However, there are many critical issues associated with treatment of metastatic disease with miRrelated agents which are not discussed in this review and are summarized in (32-34). For therapeutic intervention there are two concepts: preventive treatment before the tumor has colonized the parenchyma of distant organs such as the liver and treatment of established metastases. Preventive treatment is a critical issue due to potential toxicity issues associated with long-term treatment. Treatment of distant metastases with miR-related agents should result in a cytotoxic effect on metastatic disease, alone or in combination with other agents. Many problems are asociated with the treatment of distant metastases such as their heterogeneity, their torturous vasculature, elevated hydrostatic pressure causing poor drug penetration and resistance against drugs, which have an effect on the primary tumor (159-161). Proof-of-concept for treatment of metastatic disease has been shown with alpha particles emitting radionuclides alone or linked to monoclonal antibodies and immuno-therapy with antibodies directed against immune checkpoint targets such as PD-1, PD-1L and CTLA4 (159-162). In preclinical models, development and 
growth of metastases can be monitored by non-invasive imaging methods such as bioluminescnce or MRI (159). Metastasis modulating capability of other miRs are evaluated in the experimental metastasis model (tail vein injection) ( $\mathrm{n}=11: 15 \mathrm{a} / 16-1,22,34 \mathrm{a}, 126,143,214,218,335,499-5 \mathrm{p}$, 1269a and 4775), spontaneous metastasis after subcutaneous implantation $(n=3: 30 c, 182,544 a)$, intrasplenic injection and dissemination to the liver and peritoneum $(n=8: 15 b, 181 \mathrm{a}$, 196a-5p, 212, 214, 384, 493, 520c), orthotopic implantation into the caecum $(n=5: 103 / 107,192,200 b-3 p, 885-5 p, 1269 a)$, intrahepatic metastasis assay $(\mathrm{n}=1,374 \mathrm{a})$ and the CAM assay in chicken embryos ( $n=6$ : let-7c, 30e-5p, 135b, 182, 210, 218). Of note: miRs -218 and -1269 a have been evaluated each in two in vivo models. A sub-category of identified miRs affects tumor growth in addition to modulating metastasis (n=9: let-7c, 30c, 30e-5p, 103/107, 126, 200b-3p, $214,374 \mathrm{a}$ and $499-5 \mathrm{p}$ ). The steps of the metastatic cascade affected by the corresponding miRs are not defined and a reduction of metastatic nodules in distant organs could be due modulation of intra- and extravastion or colonization of distant organs. An impact of corresponding miRs on the size of the nodules might be an indicator of modulation of growth of distant metastases, but modulation of intra- and extravasation, or colonization can not be excluded. Evaluation of CRC-related in vivo models with established liver metastasis and treatment with miR-related agents is not addressed in the in vivo models described in this review and should be investigated in future in vivo models (163). Noteworthy, 17 of the described miRs are associated with prognosis in patients with CRC (let-7c, miRs- 15b, 103/107, 143, 181, 182, 196a-5p, 212, 214, 335, 374a, 384, 499-5p, 520c, 544a, 1269a, 4775).

In the near past, miR-based therapeutic agents have witnessed serious drawbacks in clinical studies addressing kidney disease, hepatitis $\mathrm{C}$ infection and cancer, mostly due to serious side-effects (164). Clinical evaluation of secondgeneration miRs with an improved side-effect profile is underway. In August 2018, the FDA has approved an RNAi drug, Onpattro (Alnylam Pharmaceuticals), acting on the liver for treatment of patients with transerythyrin amyloidosis and polyneuropathy (25). Multiple RNAi-based drug candidates are in Phase I, II or III clinical studies for renal, liver and ocular indications. The next upcoming years will show whether miR-based agents will play a game changing role in oncology and metastatic disease.

\section{Conflicts of Interest}

UB and SA are and UHW was an employee by Roche.

\section{Authors' Contributions}

UHW, UB and SA jointly prepared the manuscript and the figures.

\section{References}

1 Balacescu O, Sur D, Cainap C, Visan S, Cruceriu D, ManzatSaplacan R, Muresan MS, Balacescu L, Lisencu C and Irimie A: The impact of miRNA in colorectal cancer progression and its liver metastases. Int J Mol Sci 19: pii: E3711, 2018. PMID: 30469518. DOI: 10.3390/ijms19123711

2 Stein U and Schlag PM: Clinical, biological and molecular aspects of metastasis in colorectal cancer. Recent Results Cancer Res 176: 61-80, 2007. PMID: 17607917.

3 Fearon ER and Vofelstein B: A genetic model of colorectal tumorigenesis. Cell 61: 759-767, 1990. PMID: 2188735.

4 Markowitz SD and Bertagnoli MM: Molecular origins of cancer: Molecular basis of colorectal cancer. N Engl J Med 361: 24492460, 2009. PMID: 20018966. DOI: 10.1056/NEJMra0804588

5 Snyder C and Hampel H: Hereditary colorectal cancer syndromes. Sem Oncol Nurs 35: 58-78, 2019. PMID: 30665732. DOI: $10.1016 /$ j.soncn.2018.12.011

6 Tariq K and Ghias K: Colorectal cancer carcinogenesis: a review of mechanisms. Cancer Biol Med 13: 120-135, 2016. PMID: 27144067. DOI: $10.28092 / \mathrm{j}$.issn.2095-3941.2015.0103

7 Devarakonda A: Diagnosis and treatment of colorectal cancer. RRJMHS 5: 1-15, 2016.

8 Yaghoubi N, Soltani A, Ghavzini K, Hassanian SM and Hashemy SI: PD-1/ PD-L1 blockade as a novel treatment for colorectal cancer. Biomed Pharmaccother 110: 312-318, 2019. PMID: 30522017. DOI: 10.1016/j.biopha.2018.11.105

9 Passardi A, Canale M, Valgiusi M and Ulivi P: Immune checkpoints as a target for colorectal cancer treatment. Int J Mol Sci 18: Pii: E1324, 2017. PMID: 28635639. DOI: 10.3390/ijms18061324

10 Pachmayr E, Treese C and Stein U: Underlying mechanisms for distant metastasis - molecular biology. Visc Med 33: 11-20, 2017. PMID: 28785563. DOI: $10.1159 / 000454696$

11 Cook AD, Single R and McCahill LE: Surgical resection of primary tumors in patients who present with stage IV colorectal cancer: an analysis of surveillance, epidemiology, and end results data, 1988 to 2000. Ann Surg Oncol 12: 637-645, 2005. PMID: 15965730. DOI: 10.1245/ASO.2005.06.012

12 Qui M, Hu J, Yang D, Cosgrove DP and Xu R. Pattern of distant metastases in colorectal cancer. A SEER based study. Oncotarget 6: 38658-38666, 2015. PMID: 26484417. DOI:10.18632/ oncotarget.6130

13 Disibio G and French SW: Metastatic patterns of cancers: Results from a large autopsy study. Arch Pathol Lab Med 132: 931-939, 2008. PMID: 18517275. DOI: 10.1043/15432 165(2008)132[931:MPOCRF]2.0.CO;2

14 Hess KR, Varadhachary GR, Taylor SH, Wei W, Raber MN, Lenzi $\mathrm{R}$ and Abbruzzese JL: Metastatic patterns in adenocarcinoma. Cancer 106: 1624-1633, 2006. PMID: 16518827. DOI: $10.1002 /$ cncr. 21778

15 Weiss L, Grundmann E, Torhorst J, Hartveit F, Moberg I, Eder M, Fenoglio-Preiser CM, Napier J, Horne CH and Lopez MJ: Haematogenous metastatic patterns in colonic carcinoma: an analysis of 1541 necropsies. J Pathol 150: 195-203, 1986. PMID: 3806280. DOI: 10.1002/path.1711500308

16 Tomlinson JS, Jarnagin WR, DeMatteo RP, Fong Y, Kornprat P, Gonen M, Kemeny N, Brennan MF, Blumgart LH and D'Angelica M: Actual 10-year survival after resection of colorectal liver metastases defines cure. J Clin Oncol 25: 45754580, 2007. PMID: 17925551. DOI: 10.1200/JCO.2007.11.0833 
17 Weidle UH, Birzele $\mathrm{F}$ and Krüger A: Molecular targets and pathways involved in liver metastasis of colorectal cancer. Clin Exp Metastasis 32: 623-635, 2015. PMID: 26104118. DOI: $10.1007 / \mathrm{s} 10585-015-9732-3$

18 Denève E, Riethdorf S, Ramos J, Nocca D, Coffy A, Daurès JP, Maudelonde T, Fabre JM, Pantel K and Alix-Panabières C: Capture of viable circulating tumor cells in the liver of colorectal cancer patients. Clin Chem 59: 1384-1392, 2013. PMID: 23695297. DOI: 10.1373/clinchem.2013.202846

19 Fidler IJ: The pathogenesis of cancer metastasis: the „seed and soil“" hypothesis revisited. Nat Rev Cancer 3: 453-458, 2003. PMID: 12778135. DOI: 10.1038/nrc1098

20 Sceneay J, Smyth MJ and Möller A: The pre-metastatic niche: finding common ground. Cancer Metastasis Rev 32: 449-464, 2013. PMID: 23636348. DOI: 10.1007/s10555-013-9420-1

21 Wan K, Pantel K and Kang Y: Tumor metastasis: moving new biological insights into the clinic. Nat Med 19: 1450-1464, 2013. PMID: 24202397. DOI: 10.1038/nm.3391

22 Ishaque N, Abba ML, Hauser C, Patil N, Paramasivam N, Huebschmann D, Leupold JH, Balasubramanian GP, Kleinheinz K, Toprak UH, Hutter B, Benner A, Shavinskaya A, Zhou C, Gu Z, Kerssemakers J, Marx A, Moniuszko M, Kozlowski M, Reszec J, Niklinski J, Eils J, Schlesner M, Eils R, Brors B and Allgayer $\mathrm{H}$ : Whole genome sequencing puts forward hypotheses on metastasis evolution and therapy in colorectal cancer. Nat Comm 9: 4782, 2018. PMID: 30429477. DOI: 10.1038/s41467018-07041-Z

$23 \mathrm{Li} \mathrm{Z}$ and Rana TM: Therapeutic targeting of microRNAs. Current status and future challenges. Nat Rev Drug Discov 13: 622-638, 2014. PMID: 25011539. DOI: $10.1038 / \operatorname{nrd} 4359$

24 Rupaimoole R and Slack FJ: MicroRNA therapeutics: towards a new era for the management of cancer and other diseases. Nat Rev Drug Discov 16: 203-222, 2017. PMID: 28209991. DOI: 10.1038/nrd.2016.246

25 Setten RL, Rossi JJ and Han SP: The current state and future directions of RNAi-based therapeutics. Nat Rev Drug Discov 18: 421-446, 2019. PMID: 30846871. DOI: 10.1038/s41573019-0017-4

26 Lam JK, Chow MY, Zhang Y and Leung SW: siRNA versus miRNA as therapeutics for gene silencing. Mol Ther Nucleic Acids 4: e252, 2015. PMID: 26372022. DOI: 10.1038/mtna. 2015.23

27 Peter ME: Targeting of mRNAs by multiple miRNAs: the next step. Oncogene 29: 2161-2164, 2010. PMID: 20190803. DOI: 10.1038/onc. 2010.59

28 Garzon R, Calin GA and Croce CM: MicroRNAs in cancer. Ann Rev Med 60: 167-179, 2009. PMID: 19630570. DOI: 10.1146/annurev.med.59.053006.104707

29 Calin GA, Cimmino A, Fabbri M, Ferracin M, Wojcik SE, Shimizu M, Taccioli C, Zanese N, Garzon R, Ageilan RI, Alder H, Volinia S, Rassanti L, Liu X, Liu CG, Kipps TJ, Negrini M and Croce CM: MiR-15a and miR-16-1 cluster functions in human leukemia. Proc Natl Acad Sci USA 105: 5166-5171, 2008. PMID: 18362358. DOI: 10.1073/pnas.0800121105

30 Calin GA, Dumitru CD, Shimizu M, Bich R, Zupo S, Noch E, Rattan S, Keating M, Rai K, Rassenti 1, Kipps T, Negrini M, Bullrich R and Croce CM: Frequent deletions and down-regulation of micro-RNA genes miR15 and miR16 at 13q14 in chronic lymphocytic leukemia. Proc Natl Acad Sci USA 99: 15524-15529, 2002. PMID: 12434020. DOI: 10.1073/pnas.242606799
31 Weidle UH, Birzele F, Kollmorgen G and Nopara A: Potential microRNA-related targets for therapeutic intervention with ovarian cancer metastasis. Cancer Genomics Proteomics 15: 115, 2018. PMID: 29275359. DOI: 10.21873/cgp.20061

32 Weidle UH, Dickopf S, Hintermair C, Kollmorgen F, Birzele F and Brinkmann U: The role of microRNAs in breast cancer metastasis: preclinical validation and potential therapeutic targets. Cancer Genomics Proteomics 15: 17-39, 2018. PMID: 29275360. DOI: $10.21873 /$ cgp.20062

33 Weidle UH, Epp A, Birzele F and Brinkmann U: The functional role of prostate cancer metastasis-related microRNAs. Cancer Proteomics 16: 1-19, 2019. PMID: 30587496. DOI: 10.21873/cgp.20108

34 Weidle UH, Birzele F and Nopora A: microRNAs as potential targets for therapeutic intervention with metastasis of non-small cell lung cancer. Cancer Genomics Proteomics 16: 99-119, 2019. PMID: 30850362. DOI: 10.21873/cgp.20116

35 Li J, Chen Y, Guo X, Zhou L, Jia Z, Tang Y, Lin L, Liu W and Ren C: Inhibition of miR-15b decreases cell migration and metastasis in colorectal cancer. Tumor Biol 37: 8765-8773, 2016. PMID: 26743779. DOI: 10.1007/s13277-015-4396-9

36 Xie F, Ye L, Ta M, Zhang L and Jiang WG: MTSS1: a multifunctional protein and its role in cancer invasion and metastasis. Front Biosci (Schol Ed) 3: 621-631, 2011. PMID: 21196400. DOI: $10.2741 / \mathrm{s} 175$

37 Rubinek T and Wolf I: The role of alpha-Klotho as a universal tumor suppressor. Vit Horm 101: 197-214, 2016. PMID: 27125743. DOI: 10.1016/bs.vh.2016.03.001

38 Tang X, Wang Y, Fan Z, Ji G, Wang M, Lin J, Huang S and Meltzer SJ: Klotho: a tumor suppressor and modulator of the Wnt/ $\beta$-catenin pathway in human hepatocellular carcinoma. Lab Invest 96: 197-205, 2016. PMID: 26237271. DOI: 10.1038/labinvest.2015.86

39 Doi S, Zou Y, Togao O, Pastor JV, John GB, Wang L, Shiizaki K, Gotschall R, Schiavi S, Yorioka N, Takahashi M, Boothman DA and Kuro-o M: Klotho inhibits transforming growth factorbeta1 (TGF-beta1) signaling and suppresses renal fibrosis and cancer metastasis in mice. J Biol Chem 286: 8655-8665, 2011. PMID: 21209102. DOI: 10.1074/jbc.M110.174037

40 Chen HY, Lin YM, Chung HC, Lang YD, Lin CJ, Huang J, Wang WC, Lin FM, Chen Z, Huang HD, Shyy JY, Liang JT, Chen RH: Chen HY, Lin YM, Chung HC, Lang YD, Lin CJ, Huang J, Wang WC, Lin FM, Chen Z, Huang HD, Shyy JY, Liang JT and Chen RH: miR-103/107 promote metastasis of colorectal cancer by targeting the metastasis suppressors DAPK and KLF4. Cancer Res 72: 3631-3641, 2012. PMID: 22593189. DOI: $10.1158 / 0008-5472$

41 Kuo JC, Wang WJ, Yao CC, Wu PR and Chen RH: The tumor suppressor DAPK inhibits cell motility by blocking the integrinmediated polarity pathway. J Cell Biol 172: 619-631, 2006. PMID: 16476779 . DOI: $10.1083 /$ jcb.200505138

42 Chen HY, Lee YR and Chen RH: The functions and regulations of DAPK in cancer metastasis. Apoptosis 19: 364-370, 2014. PMID: 24166138. DOI: 10.1007/s10495-013-0923-6

43 Chen HY, Hu JY, Chen TH, Lin YC, Liu X, Lin MY, Lang YD, Yen $\mathrm{Y}$ and Chen RH: KLHL39 suppresses colon cancer metastasis by blocking KLHL20-mediated PML and DAPK ubiquitination. Oncogene 34: 5141-5151, 2015. PMID: 25619834. DOI: $10.1038 /$ onc 2014.435

44 Ghaleb AM, Elkarim EA, Bialkowska AB, Yang VW, Yee DS, Tang Y, Li X, Liu Z, Guo Y, Ghaffar S, McQueen P, Atreya D, 
Xie J, Simoneau AR, Hoang BH and Zi X: KLF4 suppresses tumor formation in genetic and pharmacological models of colonic tumorigenesis. Mol Cancer Res 14: 385-396, 2016. PMID: 26839262. DOI: 10.1158/1541-7786.MCR-15-0410

45 Yang MH, Yu J, Jiang DM, Li WL, Wang S and Ding YQ: microRNA-182 targets special AT-rich sequence-binding protein 2 to promote colorectal cancer proliferation and metastasis. J Transl Med 12: 109, 2014. PMID: 24884732. DOI: 10.1186/1479-5876-12-109

46 Brocato J and Costa M: SATB 1 and 2 in colorectal cancer. Carcinogenesis 36: 186-191, 2015. PMID: 25543122. DOI: 10.1093/carcin/bgu322

47 Uhlén M, Fagerberg L, Hallström BM, Lindskog C, Oksvold P, Mardinoglu A, Sivertsson Å, Kampf C, Sjöstedt E, Asplund A, Olsson I, Edlund K, Lundberg E, Navani S, Szigyarto CA, Odeberg J, Djureinovic D, Takanen JO, Hober S, Alm T, Edqvist $\mathrm{PH}$, Berling H, Tegel H, Mulder J, Rockberg J, Nilsson P, Schwenk JM, Hamsten M, von Feilitzen K, Forsberg M, Persson L, Johansson F, Zwahlen M, von Heijne G, Nielsen J and Pontén F: Proteomics. Tissue-based map of the human proteome. Science 347: 1260419, 2015. PMID: 25613900. DOI: 10.1126/science.1260419

48 Wang S, Zhou J, Wang XY, Hao JM, Chen JZ, Zhang XM, Jin H, Liu L, Zhang YF, Liu J, Ding YQ and Li JM: Downregulated expression of SATB2 is associated with metastasis and poor prognosis in colorectal cancer. J Pathol 219: 114-122, 2009. PMID: 19557828. DOI: $10.1002 /$ path.2575

49 Liu X, Zhang Z, Sun L, Chai N, Tang S, Jin J, Hu H, Nie Y, Wang X, Wu K, Jin H and Fan D: MicroRNA-499-5p promotes cellular invasion and tumor metastasis in colorectal cancer by targeting FOXO4 and PDCD4. Carcinogenesis 32: 1798-1805, 2011. PMID: 21934092. DOI: $10.1093 /$ carcin/bgr213

50 Tang ED, Nuñez G, Barr FG and Guan KL: Negative regulation of the forkhead transcription factor FKHR by Akt. J Biol Chem 274: 16741-16746, 1999. PMID: 10358014. DOI: $10.1074 / \mathrm{jbc} .274 .24 .16741$

51 Brunet A, Bonni A, Zigmond MJ, Lin MZ, Juo P, Hu LS, Anderson MJ, Arden KC, Blenis J and Greenberg ME: Akt promotes cell survival by phosphorylating and inhibiting a Forkhead transcription factor. Cell 96: 857-868, 1999. PMID: 10102273.

52 Wei ZT, Zhang X, Wang XY, Gao F, Zhou CJ, Zhu FL, Wang Q, Gao Q, Ma CH, Sun WS, Fu QZ, Chen YH and Zhang LN: PDCD4 inhibits the malignant phenotype of ovarian cancer cells. Cancer Sci 100: 1408-1413, 2009. PMID: 19493270. DOI: 10.1111/j.1349-7006.2009.01210.x

53 Wang Q, Sun Z and Yang HS: Downregulation of tumor suppressor Pdcd4 promotes invasion and activates both betacatenin/Tcf and AP-1-dependent transcription in colon carcinoma cells. Oncogene 27: 1527-1535, 2008. PMID: 17828298. DOI: 10.1038/sj.onc.1210793

54 Long J, Yin Y, Guo H, Li S, Sun Y, Zeng C and Zhu W: The mechanisms and clinical significance of PDCD4 in colorectal cancer. Gene 680: 59-64, 2019. PMID: 30243936. DOI: 10.1016/j.gene.2018.09.034

55 Mudduluru G, Abba M, Batliner J, Patil N, Scharp M, Lunavat TR, Leupold JH, Oleksiuk O, Juraeva D, Thiele W, Rothley M, Benner A, Ben-Neriah Y, Sleeman J and Allgayer H: A systematic approach to defining the microRNA landscape in metastasis. Cancer Res 75: 3010-3119, 2019. PMID: 26069251. DOI: 10.1158/0008-5472.CAN-15-0997
56 Lipkowitz S and Weissman AM: RINGs of good and evil: RING finger ubiquitin ligases at the crossroads of tumour suppression and oncogenesis. Nat Rev Cancer 11: 629-643, 2011. PMID: 21863050. DOI: $10.1038 / \mathrm{nrc} 3120$

57 McDaniel SL and Strahl BD: Shaping the cellular landscape with Set2/SETD2 methylation. Cell Mol Life Sci 744: 3317-3334, 2017. PMID: 28386724. DOI: 10.1007/s00018-017-2517-x

58 Nakajima S, Doi R, Toyoda E, Tsuji S, Wada M, Koizumi M, Tulachan SS, Ito D, Kami K, Mori T, Kawaguchi Y, Fujimoto $\mathrm{K}$, Hosotani $\mathrm{R}$ and Imamura $\mathrm{M}$ : N-cadherin expression and epithelial-mesenchymal transition in pancreatic carcinoma. Clin Cancer Res 10: 4125-4133, 2004. PMID: 15217949. DOI: 10.1158/1078-0432.CCR-0578-03

59 Ji D, Chen Z, Li M, Zhan T, Yao Y, Zhang Z, Xi J, Yan L and Gu J: MicroRNA-181a promotes tumor growth and liver metastasis in colorectal cancer by targeting the tumor suppressor WIF-1. Mol Cancer 13: 86, 2014. PMID: 24755295. DOI: 10.1186/1476-4598-13-86

60 Malinauskas T: Docking of fatty acids into the WIF domain of the human Wnt inhibitory factor-1. Lipids 43: 227-230, 2008. PMID: 18256869. DOI: 10.1007/s11745-007-3144-3

61 Wissmann C, Wild PJ, Kaiser S, Roepcke S, Stoehr R, Woenckhaus M, Kristiansen G, Hsieh JC, Hofstaedter F, Hartmann A, Knuechel R, Rosenthal A and Pilarsky C: WIF1, a component of the Wnt pathway, is down-regulated in prostate, breast, lung, and bladder cancer. J Pathol 201: 204-212, 2003. PMID: 14517837. DOI: 10.1002/path.1449

62 Yee DS, Tang Y, Li X, Liu Z, Guo Y, Ghaffar S, McQueen P, Atreya D, Xie J, Simoneau AR, Hoang BH and Zi X: The Wnt inhibitory factor 1 restoration in prostate cancer cells was associated with reduced tumor growth, decreased capacity of cell migration and invasion and a reversal of epithelial to mesenchymal transition. Mol Cancer 9: 162, 2010. PMID: 20573255. DOI: 10.1186/1476-4598-9-162

63 Xin H, Wang C and Liu Z: miR-196a-5p promotes metastasis of colorectal cancer via targeting ІкB $\alpha$. ВMC Cancer 19: 30, 2019 PMID: 30621631. DOI: 10.1186/s12885-018-5245-1

64 Karin M, Cao Y, Greten FR and Li ZW: NF-kappaB in cancer: from innocent bystander to major culprit. Nat Rev Cancer 2: 301-304, 2002. PMID: 12001991. DOI: 10.1038/nrc780

65 Sun S, Su C, Zhu Y, Li H, Liu N, Xu T, Sun C and Lv Y: MicroRNA-544a regulates migration and invasion in colorectal cancer cells via regulation of homeobox A10. Dig Dis Sci 61: 2535-2544, 2016. PMID: 27165435. DOI: 10.1007/s10620-0164186-2

66 Lamouille S, Xu J and Derynck R: Molecular mechanisms of epithelial-mesenchymal transition. Nat Rev Mol Cell Biol 15: 178-196, 2014. PMID: 24556840. DOI: $10.1038 / \mathrm{nrm} 3758$

67 Yilmaz M and Christofori G: EMT, the cytoskeleton, and cancer cell invasion. Cancer Metastasis Rev 28: 15-33, 2009. PMID: 19169796. DOI: 10.1007/s10555-008-9169-0

68 Lam CS, Ng L, Chow AK, Wan TM, Yau S, Cheng NS, Wong SK, Man JH, Lo OS, Foo DC, Poon JT, Pang RW1 and Law WL: Identification of microRNA 885-5p as a novel regulator of tumor metastasis by targeting CPEB2 in colorectal cancer. Oncotarget 8: 26858-26970, 2017. PMID: 28460469. DOI:10.18632/oncotarget.15844

69 Nairismägi ML, Vislovukh A, Meng Q, Kratassiouk G, Beldiman C, Petretich M, Groisman R, Füchtbauer EM, HarelBellan A and Groisman I: Translational control of TWIST1 
expression in MCF-10A cell lines recapitulating breast cancer progression. Oncogene 31: 4960-4966, 2012. PMID: 22266852. DOI: $10.1038 /$ onc .2011 .650

70 Yang J, Mani SA, Donaher JL, Ramaswamy S, Itzykson RA, Come C, Savagner P, Gitelman I, Richardson A and Weinberg RA: Twist, a master regulator of morphogenesis, plays an essential role in tumor metastasis. Cell 117: 927-939, 2004. PMID: 15210113. DOI: 10.1016/j.cell.2004.06.006

71 Richter JD: CPEB: A life in translation. Trends Biochem Sci 32: 279-285. PMID: 17481902. DOI: 10.1016/j.tibs.2007.04.004

72 Bu P, Wang L, Chen KY, Rakhilin N, Sun J, Closa A, Tung KL, King S, Kristine Varanko A, Xu Y, Huan Chen J, Zessin AS, Shealy J, Cummings B, Hsu D, Lipkin SM, Moreno V, Gümüş $\mathrm{ZH}$ and Shen X: miR-1269 promotes metastasis and forms a positive feedback loop with TGF- $\beta$. Nat Commun 6: 6879, 2015. PMID: 25872451. DOI: $10.1038 /$ ncomms7879

73 Zhao S, Sun H, Jiang W, Mi Y, Zhang D, Wen Y, Cheng D, Tang H, Wu S, Yu Y, Liu X, Cui W, Zhang M, Sun X, Zhou Z, Peng $\mathrm{Z}$ and Yan D: miR-4775 promotes colorectal cancer invasion and metastasis via the Smad7/TGF $\beta$-mediated epithelial to mesenchymal transition. Mol Cancer 16: 12, 2017. PMID: 28095858. DOI: 10.1186/s12943-017-0585-z

74 Bhola NE, Balko JM, Dugger TC, Kuba MG, Sánchez V, Sanders M, Stanford J, Cook RS and Arteaga CL: TGF- $\beta$ inhibition enhances chemotherapy action against triple-negative breast cancer. J Clin Invest 123: 1348-1358, 2013. PMID: 23391723. DOI: $10.1172 /$ JCI65416

75 Mu Y, Sundar R, Thakur N, Ekman M, Gudey SK, Yakymovych M, Hermansson A, Dimitriou H, Bengoechea-Alonso MT, Ericsson J, Heldin CH and Landström M: TRAF6 ubiquitinates TGF $\beta$ type I receptor to promote its cleavage and nuclear translocation in cancer. Nat Commun 2: 330, 2011. PMID: 21629263. DOI: $10.1038 /$ ncomms 1332

76 Jung B, Staudacher JJ and Beauchamp D: Transforming growth factor $\beta$ superfamily signaling in development of colorectal cancer. Gastroenterology 152: 36-52, 2017. PMID: 27773809. DOI: 10.1053 /j.gastro.2016.10.015

77 Calon A, Espinet E, Palomo-Ponce S, Tauriello DV, Iglesias M, Céspedes MV, Sevillano M, Nadal C, Jung P, Zhang XH, Byrom D, Riera A, Rossell D, Mangues R, Massagué J, Sancho E and Batlle E: Dependency of colorectal cancer on a TGF- $\beta$-driven program in stromal cells for metastasis initiation. Cancer Cell 22: 571-584, 2012. PMID: 23153532. DOI: 10.1016/j.ccr.2012.08.013

78 Han HB, Gu J, Zuo HJ, Chen ZG, Zhao W, Li M, Ji DB, Lu YY and Zhang ZQ: Let-7c functions as a metastasis suppressor by targeting MMP11 and PBX3 in colorectal cancer. Pathol 226: 544-555, 2012. PMID: 21984339. DOI: 10.1002/path.3014

79 Wang YX, Chen YR, Liu SS, Ye YP, Jiao HL, Wang SY, Xiao ZY, Wei WT, Qiu JF, Liang L, Liao WT and Ding YQ: MiR-384 inhibits human colorectal cancer metastasis by targeting KRAS and CDC42. Oncotarget 7: 84826-84838, 2016. PMID: 27769041. DOI: $10.18632 /$ oncotarget.12704

80 Sahai E and Marshall CJ: RHO-GTPases and cancer. Nat Rev Cancer 2: 133-142, 2002. PMID: 12635176. DOI: 10.1038/nrc725

81 Vaughn CP, Zobell SD, Furtado LV, Baker CL and Samowitz WS: Frequency of KRAS, BRAF, and NRAS mutations in colorectal cancer. Genes Chromosomes Cancer 50: 307-312, 2011. PMID: 21305640 . DOI: $10.1002 / \mathrm{gcc} .20854$

82 Skoglund J, Emterling A, Arbman G, Anglard P and Sun XF: Clinicopathological significance of stromelysin-3 expression in colorectal cancer. Oncology 67: 67-72, 2004. PMID: 15459498. DOI: $10.1159 / 000080288$

83 Lamprecht S, Kaller M, Schmidt EM, Blaj C, Schiergens TS, Engel J, Jung A, Hermeking H, Grünewald TGP, Kirchner T and Horst D: PBX3 is part of an EMT regulatory network and indicates poor outcome in colorectal cancer. Clin Cancer Res 24: 1974-1986, 2018. PMID: 29391352. DOI: 10.1158/10780432.CCR-17-2572

84 Qadir MI, Parveen A and Ali M: Cdc42: Role in cancer management. Chem Biol Drugs Des 86: 432-439, 2015. PMID: 25777055. DOI: $10.1111 /$ cbdd.12556

85 Laudato S, Patil N, Abba ML, Leupold JH, Benner A, Gaiser T, Marx A and Allgayer H: P53-induced miR-30e-5p inhibits colorectal cancer invasion and metastasis by targeting ITGA6 and ITGB1. Int J Cancer 141: 1879-1890, 2017. PMID: 28656629. DOI: $10.1002 / \mathrm{ijc} .30854$

86 Blandin AF, Renner G, Lehmann M, Lelong-Rebel I, Martin S and Dontenwill M: $\beta 1$ Integrins as therapeutic targets to disrupt hallmarks of cancer. Front Pharmacol 6: 279, 2015. PMID: 26635609. DOI: $10.3389 /$ fphar.2015.00279

87 Brakebusch C, Wennerberg K, Krell HW, Weidle UH, Sallmyr A, Johansson $S$ and Fässler R: $\beta 1$ integrin promotes but is not essential for metastasis of ras-myc transformed fibroblasts. Oncogene 18: 3852-3867, 1999. PMID: 10445848. DOI: 10.1038/sj.onc. 1202770

88 Yuan W, Guo YQ, Li XY, Deng MZ, Shen ZH, Bo CB, Dai YF, Huang MY, Yang ZY, Quan YS, Tian L and Wang X: MicroRNA126 inhibits colon cancer cell proliferation and invasion by targeting the chemokine (C-X-C motif) receptor 4 and Ras homolog gene family, member A, signaling pathway. Oncotarget 13: 60230-60244, 2016. PMID: 27517626. DOI: 10.18632/oncotarget.11176

89 Yagi H, Tan W, Dillenburg-Pilla P, Armando S, Amornphimoltham P, Simaan M, Weigert R, Molinolo AA, Bouvier M and Gutkind JS: A synthetic biology approach reveals a CXCR4-G13-Rho signaling axis driving transendothelial migration of metastatic breast cancer cells. Sci Signal 4: ra60, 2011. PMID: 21934106. DOI: 10.1126/scisignal.2002221

90 Schimanski CC, Galle PR and Moehler M: Chemokine receptor CXCR4-prognostic factor for gastrointestinal tumors. World J Gastroenterol 14: 4721-4724, 2008. PMID: 18720530. DOI: 10.3748/wjg.14.4721

91 Li YP, Pang J, Gao S, Bai PY, Wang WD, Kong P and Cui Y: Role of CXCR4 and SDF1 as prognostic factors for survival and the association with clinicopathology in colorectal cancer: A systematic meta-analysis. Tumor Biol 39: 1010428317706206, 2017. PMID: 28621237. DOI: $10.1177 / 1010428317706206$

92 Guo H, Chen Y, Hu X, Qian G, Ge S and Zhang J: The regulation of Toll-like receptor 2 by miR-143 suppresses the invasion and migration of a subset of human colorectal carcinoma cells. Mol Cancer 12: 77, 2013. PMID: 23866094. DOI: $10.1186 / 1476-4598-12-77$

93 Kim S and Karin M: Role of TLR2-dependent inflammation in metastatic progression. Ann NY Acad Sci 1217: 191-206, 2011. PMID: 21276007. DOI: 10.1111/j.1749-6632.2010.05882.x

94 Akira S and Takeda K: Toll-like receptor signalling. Nat Rev Immunol 4: 499-511, 2004. PMID: 15229469. DOI: $10.1038 /$ nri1391

95 Kawai $\mathrm{T}$ and Akira $\mathrm{S}$ : Innate immune recognition of viral infection. Nat Immunol 7: 131-137, 2006. PMID: 16424890. DOI: $10.1038 /$ ni1303 
96 Chen DL, Wang ZQ, Zeng ZL, Wu WJ, Zhang DS, Luo HY, Wang F, Qiu MZ, Wang DS, Ren C, Wang FH, Chiao LJ, Pelicano $\mathrm{H}$, Huang $\mathrm{P}, \mathrm{Li} \mathrm{YH}$ and $\mathrm{Xu} \mathrm{RH}$ : Identification of microRNA-214 as a negative regulator of colorectal cancer liver metastasis by way of regulation of fibroblast growth factor receptor 1 expression. Hepatology 60: 598-609, 2014. PMID: 24616020. DOI: 10.1002/hep.27118

97 Yang F, Zhang Y, Ressler SJ, Ittmann MM, Ayala GE, Dang TD, Wang F and Rowley DR: FGFR1 is essential for prostate cancer progression and metastasis. Cancer Res 73: 3716-3724, 2013. PMID: 23576558. DOI: 10.1158/0008-5472.CAN-12-3274

98 Sato T, Oshima T, Yoshihara K, Yamamoto N, Yamada R, Nagano Y, Fujii S, Kunisaki C, Shiozawa M, Akaike M, Rino Y, Tanaka K, Masuda M and Imada T: Overexpression of the fibroblast growth factor receptor-1 gene correlates with liver metastasis in colorectal cancer. Oncol Rep 21: 211-216, 2009. PMID: 19082464.

99 Okamoto K, Ishiguro T, Midorikawa Y, Ohata H, Izumiya M, Tsuchiya N, Sato A, Sakai H and Nakagama H: miR-493 induction during carcinogenesis blocks metastatic settlement of colon cancer cells in liver. EMBO J 31: 1752-1763, 2012. PMID: 22373578. DOI: 10.1038/emboj.2012.25

100 Chitnis MM, Yuen JS, Protheroe AS, Pollak M and Macaulay VM: The type 1 insulin-like growth factor receptor pathway. Clin Cancer Res 14: 6364-6370, 2008. PMID: 18927274. DOI: 10.1158/1078-0432.CCR-07-4879

101 Shali H, Ahmadi M, Kafil HS, Dorosti A and Yousefi M: IGF1R and c-met as therapeutic targets for colorectal cancer. Biomed Pharmacother 82: 528-536, 2016. PMID: 27470393. DOI: 10.1016/j.biopha.2016.05.034

102 Hermeking $\mathrm{H}$ : MicroRNAs in the p53 network: Micromanagement of tumour suppression. Nat Rev Cancer 12: 613-626, 2012. PMID: 22898542. DOI: $10.1038 / \mathrm{nrc} 3318$

103 Aqeilan RI, Calin GA and Croce CM: miR-15a and miR-16-1 in cancer: discovery, function and future perspectives. Cell Death Differ 17: 215-220, 2010. PMID: 19498445. DOI: 10.1038/cdd.2009.69

104 Zheng H and Kang Y: Multilayer control of the EMT master regulators. Oncogene 33: 1755-1763, 2014. PMID: 23604123. DOI: $10.1038 /$ onc .2013 .128

105 Jackstadt R, Röh S, Neumann J, Jung P, Hoffmann R, Horst D, Berens C, Bornkamm GW, Kirchner T, Menssen A and Hermeking H: AP4 is a mediator of epithelial-mesenchymal transition and metastasis in colorectal cancer. J Exp Med 210: 1331-1350, 2013. PMID: 23752226. DOI: 10.1084/jem.2012 0812

106 Shi L, Jackstadt R, Siemens H, Li H, Kirchner T and Hermeking $\mathrm{H}$ : p53-induced miR-15a/16-1 and AP4 form a double-negative feedback loop to regulate epithelial-mesenchymal transition and metastasis in colorectal cancer. Cancer Res 74: 532-542, 2014. PMID: 24285725. DOI: 10.1158/0008-5472.CAN-13-2203

107 Zhang Q, Yu L, Qin D, Huang R, Jiang X, Zou C, Tang Q, Chen Y, Wang G, Wang X and Gao X: Role of microRNA-30c targeting ADAM19 in colorectal cancer. PLoS ONE 10: e0120698, 2015. PMID: 25799050. DOI: 10.1371/journal.pone.0120698

108 Qi B, Newcomer RG and Sang QX: ADAM19/adamalysin 19 structure, function, and role as a putative target in tumors and inflammatory diseases. Curr Pharm Des 15: 2336-2348, 2009. PMID: 19601835.
109 Wildeboer D, Naus S, Amy Sang QX, Bartsch JW, Pagenstecher A: Metalloproteinase disintegrins ADAM8 and ADAM19 are highly regulated in human primary brain tumors and their expression levels and activities are associated with invasiveness. J Neuropathol Exp Neurol 65: 516-527, 2006. PMID: 16772875. DOI: 10.1097/01.jnen.0000229240.51490.d3

110 Roemer A, Schwettmann L, Jung M, Roigas J, Kristiansen G, Schnorr D, Loening SA, Jung K and Lichtinghagen R: Increased mRNA expression of ADAMs in renal cell carcinoma and their association with clinical outcome. Oncol Rep 11: 529-536, 2004. PMID: 14719095

111 Rokavec M, Öner MG, Li H, Jackstadt R, Jiang L, Lodygin D, Kaller M, Horst D, Ziegler PK, Schwitalla S, Slotta-Huspenina J, Bader FG, Greten FR and Hermeking H: IL-6R/STAT3/miR34a feedback loop promotes EMT-mediated colorectal cancer invasion and metastasis. J Clin Invest 124: 1853-1867, 2014 PMID: 24642471. DOI: 10.1172/JCI73531

112 Tanaka T, Kohno H, Suzuki R, Yamada Y, Sugie S and Mori H: A Novel inflammation-related mouse colon carcinogenesis model induced by azoxymethane and dextran sodium sulfate. Cancer Sci 94: 965-973, 2003. PMID: 14611673. DOI: 10.1111/j.1349-7006.2003.tb01386.x

113 Weidle UH, Klostermann S, Eggle D and Krüger A: Interleukin 6/interleukin 6 receptor interaction and its role as a therapeutic target for treatment of cachexia and cancer. Cancer Genomics Proteomics 7: 287-302, 2010. PMID: 21156962.

114 Li M, Yue GG, Song LH, Huang MB, Lee JK, Tsui SK, Fung $\mathrm{KP}$, Tan NH and Lau CB: Natural small molecule bigelovin suppresses orthotopic colorectal tumor growth and inhibits colorectal cancer metastasis via IL6/STAT3 pathway. Biochem Pharmacol 150: 191-201, 2018. PMID: 29454618. DOI: 10.1016/j.bcp.2018.02.017

115 Geng L, Chaudhuri A, Talmon G, Wisecarver JL, Are C, Brattain M and Wang J: MicroRNA-192 suppresses liver metastasis of colon cancer. Oncogene 33: 5332-5340, 2014. PMID: 24213572. DOI: 10.1038/onc.2013.478

116 Sun Z, Zhang Z, Liu Z, Qiu B, Liu K and Dong G: MicroRNA335 inhibits invasion and metastasis of colorectal cancer by targeting ZEB2. Med Oncol 31: 982, 2014. PMID: 24829139. DOI: $10.1007 / \mathrm{s} 12032-014-0982-8$

117 Fardi M, Alivand M, Baradaran B, Farshdousti Hagh M and Solali S: The crucial role of ZEB2: From development to epithelial-to-mesenchymal transition and cancer complexity. J Cell Physiol 234: 14783-14799, 2019. PMID: 30773635. DOI: $10.1002 /$ jcp.28277

$118 \mathrm{Vu}$ T and Datta PK: Regulation of EMT in Colorectal Cancer: A Culprit in Metastasis. Cancers 9: pii: E171, 2017. PMID: 29258163. DOI: $10.3390 /$ cancers9120171

119 Bürglin TR and Affolter M: Homeodomain proteins: an update. Chromosoma 125: 497-521, 2016. PMID: 26464018. DOI: 10.1007/s00412-015-0543-8

120 Kahlert C, Lahes S, Radhakrishnan P, Dutta S, Mogler C, Herpel E, Brand K, Steinert G, Schneider M, Mollenhauer M, Reissfelder C, Klupp F, Fritzmann J, Wunder C, Benner A, Kloor M, Huth C, Contin P, Ulrich A, Koch M and Weitz J: Overexpression of ZEB2 at the invasion front of colorectal cancer is an independent prognostic marker and regulates tumor invasion in vitro. Clin Cancer Res 17: 7654-7663, 2011. PMID: 22042972. DOI: 10.1158/1078-0432.CCR-102816 
121 Acloque H, Adams MS, Fishwick K, Bronner-Fraser M and Nieto MA: Epithelial-mesenchymal transitions: the importance of changing cell state in development and disease. J Clin Invest 119: 1438-1439, 2009. PMID: 19487820. DOI: $10.1172 / \mathrm{JCI} 38019$

122 Lv Z, Wei J, You W, Wang R, Shang J, Xiong Y1, Yang H, Yang $\mathrm{X}$ and Fu Z: Disruption of the c-Myc/miR-200b-3p/PRDX2 regulatory loop enhances tumor metastasis and chemotherapeutic resistance in colorectal cancer. J Transl Med 15: 257, 2017. PMID: 29258530. DOI: 10.1186/s12967-017-1357-7

123 Bertoldi M: Human peroxiredoxins 1 and 2 and their interacting protein partners; through structure toward functions of biological complexes. Protein Pept Lett 23: 69-77, 2016. PMID: 26548861.

$124 \mathrm{Lu} \mathrm{W,} \mathrm{Fu} \mathrm{Z,} \mathrm{Wang} \mathrm{H,} \mathrm{Feng} \mathrm{J,} \mathrm{Wei} \mathrm{J} \mathrm{and} \mathrm{Guo} \mathrm{J:} \mathrm{Peroxiredoxin}$ 2 knockdown by RNA interference inhibits the growth of colorectal cancer cells by downregulating Wnt/ $\beta$-catenin signaling. Cancer Lett 343: 190-199, 2014. PMID: 24125860. DOI: 10.1016/j.canlet.2013.10.002

125 Meng X, Wu J, Pan C, Wang H, Ying X, Zhou Y, Yu H, Zuo Y, Pan Z, Liu RY and Huang W: Genetic and epigenetic downregulation of microRNA-212 promotes colorectal tumor metastasis via dysregulation of MnSOD. Gastroenterology 145: 426-436.e16. 2013. PMID: 23583431. DOI: 10.1053/j.gastro.2013.04.004

126 Mohr A, Büneker C, Gough RP and Zwacka RM: MnSOD protects colorectal cancer cells from TRAIL-induced apoptosis by inhibition of Smac/DIABLO release. Oncogene 27: 763-774, 2008. PMID: 17653087. DOI: 10.1038/sj.onc.1210673

127 Kamarajugadda S, Cai Q, Chen H, Nayak S, Zhu J, He M, Jin Y, Zhang Y, Ai L, Martin SS, Tan M and Lu J: Manganese superoxide dismutase promotes anoikis resistance and tumor metastasis. Cell Death Dis 4: e504, 2013. PMID: 23429290. DOI: $10.1038 /$ cddis 2013.20

128 Kaewpila S, Venkataraman S, Buettner GR and Oberley LW: Manganese superoxide dismutase modulates hypoxia-inducible factor-1 alpha induction via superoxide. Cancer Res 68: 27812788, 2008. PMID: 18413745. DOI: 10.1158/0008-5472.CAN07-2635

129 Yoo YG, Christensen J and Huang LE: HIF-1 $\alpha$ confers aggressive malignant traits on human tumor cells independent of its canonical transcriptional function. Cancer Res 71: 12441252, 2011. PMID: 21303984. DOI: 10.1158/0008-5472.CAN$10-2360$

130 Chen Y, Jiang J, Zhao M, Luo X, Liang Z, Zhen Y, Fu Q, Deng X, Lin X, Li L, Luo R, Liu Z and Fang W: MicroRNA-374a suppresses colon cancer progression by directly reducing CCND1 to inactivate the PI3K/AKT pathway. Oncotarget 7: 41306-41319, 2016. PMID: 27191497. DOI: 10.18632/oncotarget.9320

$131 \mathrm{Fu}$ M, Wang C, Li Z, Sakamaki T and Pestell RG: Minireview: Cyclin D1: normal and abnormal functions. Endocrinology 145: 5439-5447, 2004. PMID: 15331580. DOI: 10.1210/en.20040959

132 Baldin V, Lukas J, Marcote MJ, Pagano M and Draetta G: Cyclin D1 is a nuclear protein required for cell cycle progression in G1. Genes Dev 7: 812-821, 1993. PMID: 8491378. DOI: 10.1101/gad.7.5.812

133 Xia SS, Zhang GJ, Liu ZL, Tian HP, He Y, Meng CY, Li LF, Wang ZW and Zhou T: MicroRNA-22 suppresses the growth, migration and invasion of colorectal cancer cells through a Sp1 negative feedback loop. Oncotarget 8: 36266-36278, 2017. PMID: 28422727. DOI: 10.18632/oncotarget.16742
134 Zhao Y, Zhang W, Guo Z, Ma F, Wu Y, Bai Y, Gong W, Chen Y, Cheng T, Zhi F, Zhang Y, Wang J and Jiang B: Inhibition of the transcription factor $\mathrm{Sp} 1$ suppresses colon cancer stem cell growth and induces apoptosis in vitro and in nude mouse xenografts. Oncol Rep 30: 1782-1792, 2013. PMID: 23877322. DOI: $10.3892 /$ or.2013.2627

135 Kuan CS, See Too WC and Few LL: Sp1 and Sp3 are the transcription activators of human ek1 promoter in TSA-treated human colon carcinoma cells. PLOs One 11: E0147886. PMID: 26807725. DOI: 10.1371/journal.pone. 0147886

136 Jiang BH and Liu LZ: PI3K/PTEN signaling in tumorigenesis and angiogenesis. Biochim Biophys Acta 1784: 150-158, 2008. PMID: 17964232. DOI: 10.1016/j.bbapap.2007.09.008

137 Zhang LL, Mu GG, Ding QS, Li YX, Shi YB, Dai JF and Yu HG: Phosphatase and Tensin Homolog (PTEN) represses colon cancer progression through inhibiting paxillin transcription via PI3K/AKT/NF-kB pathway. J Biol Chem 290: 15018-15029, 2015. PMID: 25873394. DOI: 10.1074/jbc.M115.641407

138 de Araujo WM, Robbs BK, Bastos LG, de Souza WF, Vidal FC, Viola JP and Morgado-Diaz JA: PTEN overexpression cooperates with lithium to reduce the malignancy and to increase cell death by apoptosis via PI3K/Akt suppression in colorectal cancer cells. J Cell Biochem 117: 458-469, 2016. PMID: 26224641. DOI: 10.1002/jcb.25294

139 Kou XX, Hao T, Meng Z, Zhou YH and Gan YH: Acetylated Sp1 inhibits PTEN expression through binding to PTEN core promoter and recruitment of HDAC1 and promotes cancer cell migration and invasion. Carcinogenesis 34: 58-67, 2013. PMID: 23104175. DOI: $10.1093 /$ carcin/bgs336

140 Stiegelbauer V, Vychytilova-Faltejskova P, Karbiener M, Pehserl AM, Reicher A, Resel M, Heitzer E, Ivan C, Bullock M, Ling H, Deutsch A, Wulf-Goldenberg A, Adiprasito JB, Stoeger H, Haybaeck J, Svoboda M, Stotz M, Hoefler G, Slaby O, Calin GA, Gerger A and Pichler M: miR-196b-5p regulates colorectal cancer cell migration and metastases through Interaction with HOXB7 and GALNT5. Clin Cancer Res 23: 5255-5266, 2017. PMID: 28533224. DOI: 10.1158/10780432.CCR-17-0023

141 Liao WT, Jiang D, Yuan J, Cui YM, Shi XW, Chen CM, Bian $\mathrm{XW}$, Deng YJ and Ding YQ: HOXB7 as a prognostic factor and mediator of colorectal cancer progression. Clin Cancer Res 17: 3569-3578, 2011. PMID: 21474578. DOI: 10.1158/10780432.CCR-10-2533

142 Chia J, Goh G and Bard F: Short O-GalNAc glycans: regulation and role in tumor development and clinical perspectives. Biochem Biophys Acta 1860: 1623-1639, 2016. PMID: 26968459. DOI: 10.1016/j.bbagen.2016.03.008

143 He GY, Hu JL, Zhou L, Zhu XH, Xin SN, Zhang D, Lu GF1, Liao WT, Ding YQ and Liang L: The FOXD3/miR-214/MED19 axis suppresses tumour growth and metastasis in human colorectal cancer. Br J Cancer 115: 1367-1378, 2016. PMID: 27811858. DOI: $10.1038 /$ bjc.2016.362

144 Poss ZC, Ebmeier CC and Taatjes DJ: The Mediator complex and transcription regulation. Crit Rev Biochem Mol Biol 48: 575-608, 2013. PMID: 24088064. DOI: 10.3109/10409238.2013.

145 Tsai KL, Tomomori-Sato C, Sato S, Conaway RC, Conaway JW and Asturias FJ: Subunit architecture and functional modular rearrangements of the transcriptional mediator complex. Cell 157: 1430-1444, 2014. PMID: 24882805. DOI: 10.1016/j.cell.2014. 05.015 
146 Schiano C, Casamassimi A, Rienzo M, de Nigris F, Sommese L and Napoli C: Involvement of Mediator complex in malignancy. Biochim Biophys Acta 1845: 66-83, 2014. PMID: 24342527. DOI: 10.1016/j.bbcan.2013.12.001

147 Zou SW, Ai K, Wang ZG, Yuan Z, Yan J and Zheng Q: The role of Med19 in the proliferation and tumorigenesis of human hepatocellular carcinoma cells. Acta Pharmacol Sin 32: 354-360, 2011. PMID: 21372827. DOI: 10.1038/aps.2010

148 Cui X, Xu D, Lv C, Qu F, He J, Chen M, Liu Y, Gao Y, Che J, Yao Y and Yu H: Suppression of MED19 expression by shRNA induces inhibition of cell proliferation and tumorigenesis in human prostate cancer cells. BMB Rep 44: 547-552, 2011. PMID: 21871180

149 Wang T, Hao L, Feng Y, Wang G, Qin D and Gu G: Knockdown of MED19 by lentivirus-mediated shRNA in human osteosarcoma cells inhibits cell proliferation by inducing cell cycle arrest in the G0/G1 phase. Oncol Res 19: 193-201, 2011. PMID: 21542455.

150 Mudduluru G, Ilm K, Fuchs S and Stein U: Epigenetic silencing of miR-520c leads to induced S100A4 expression and its mediated colorectal cancer progression. Oncotarget 8: 2108121094, 2017. PMID: 28423501. DOI: 10.18632/oncotarget. 15499

151 Ambartsumian N, Klingelhöfer $\mathrm{J}$ and Grigorian M: The multifaceted S100A4 protein in cancer and inflammation. Methods Mol Biol 1929: 339-365, 2019. PMID: 30710284. DOI: 10.1007/978-1-4939-9030-6_22

152 Fei F, Qu J, Zhang M, Li Y and Zhang S: S100A4 in cancer progression and metastasis: A systematic review. Oncotarget 8 : 73219-73239, 2017. PMID: 29069865. DOI: 10.18632/ oncotarget. 18016

153 Dahlmann M, Kobelt D, Walther W, Mudduluru G and Stein U: S100A4 in cancer metastasis: Wnt signaling-driven interventions for metastasis restriction. Cancers 20: Pii:E59, 2016. PMID: 27331819. DOI: $10.3390 /$ cancers 8060059

154 Sack U, Walther W, Scudiero D, Selby M, Aumann J, Lemos C, Fichtner I, Schlag PM, Shoemaker RH and Stein U: S100A4induced cell motility and metastasis is restricted by the Wnt/ $\beta$ catenin pathway inhibitor calcimycin in colon cancer cells. Mol Biol Cell 22: 3344-3354, 2011. PMID: 21795396. DOI: 10.1091/mbc.E10-09-0739

155 Kim E and Helfman DM: Characterization of the metastasisassociated protein, S100A4. Roles of calcium binding and dimerization in cellular localization and interaction with myosin. J Biol Chem 278: 30063-30073, 2003. PMID: 12756252. DOI: 10.1074/jbc.M304909200
156 Ambartsumian N, Klingelhöfer J, Grigorian M, Christensen C, Kriajevska M, Tulchinsky E, Georgiev G, Berezin V, Bock E, Rygaard J, Cao R, Cao Y and Lukanidin E: The metastasisassociated Mts1(S100A4) protein could act as an angiogenic factor. Oncogene 20: 4685-4695, 2001. PMID: 11498791. DOI: 10.1038/sj.onc. 1204636

157 Gongoll S, Peters G, Mengel M, Piso P, Klempnauer J, Kreipe $\mathrm{H}$ and von Wasielewski R: Prognostic significance of calciumbinding protein S100A4 in colorectal cancer. Gastroenterology 123: 1478-1484, 2002. PMID: 12404222.

158 Takenaga K, Nakanishi H, Wada K, Suzuki M, Matsuzaki O, Matsuura A and Endo H: Increased expression of S100A4, a metastasis-associated gene, in human colorectal adenocarcinomas. Clin Cancer Res 3: 2309-2316, 1997. PMID: 9815629.

159 Steeg PS: Targeting metastasis. Nat Rev Cancer 16: 201-218, 2016. PMID: 27009393. DOI: $10.1038 /$ nrc. 2016.25

160 Anderson RL, Balasas T, Callaghan J, Coombes RC, Evans J, Hall JA, Kinrade S, Jones D, Jones PS, Jones R, Marshall JF, Panico MB, Shaw JA, Steeg PS, Sullivan M, Tong W, Westwell AD, Ritchie JWA; Cancer Research UK and Cancer Therapeutics CRC Australia Metastasis Working Group. A framework for the development of effective anti-metastatic agents. Nat Rev Clin Oncol 16: 185-204, 2009. PMID: 30514977. DOI: 10.1038/s41571-018-0134-8

161 Alhumaid A, AlYousef Z, Bakhsh HA, AlGhamdi S and Aziz MA: Emerging paradigms in the treatment of liver metastases in colorectal cancer. Crit Rev Oncol Hematol 132: 39-50, 2018. PMID: 30447926. DOI: 10.1016/j.critrevonc.2018.09.011

162 Zacharakis N, Chinnasamy H, Black M, Xu H, Lu YC, Zheng Z, Pasetto A, Langhan M, Shelton T, Prickett T, Gartner J, Jia L, Trebska-McGowan K, Somerville RP, Robbins PF, Rosenberg SA, Goff SL and Feldman SA: Immune recognition of somatic mutations leading to complete durable regression in metastatic breast cancer. Nat Med 24: 724-730, 2018. PMID: 29867227. DOI: $10.1038 / \mathrm{s} 41591-018-0040-8$

163 Sebolt-Leopold JS: Development of preclinical models to understand and treat colorectal cancer. Clin Colon Rectal Surg 31: 199-204, 2018. PMID: 29720906. DOI: 10.1055/s-00371602240

164 Jones D: Setbacks shadow microRNA therapies in the clinic. Nat Biotechnol 36: 909-910, 2018 PMID: 30307922. DOI: 10.1038/nbt1018-909

Received June 15, 2020

Revised July 8, 2020

Accepted July 17, 2020 